\title{
Organizacja pracy kancelaryjnej i archiwum zakładowe Zarządu Wojewódzkiego Związku Bojowników o Wolność i Demokrację w Lublinie i podległych mu struktur*
}

\section{Związek Bojowników o Wolność i Demokrację i jego struktury na terenie województwa lubelskiego w latach 1945-1990 ${ }^{1}$}

Związek Bojowników o Wolność i Demokrację (dalej: ZBoWiD) został utworzony na Kongresie Zjednoczeniowym w Warszawie w dniach 1-2 września 1949 roku, w 10. rocznicę wybuchu II wojny światowej i ataku Niemiec na Polskę. Powstanie organizacji było wynikiem celowej polityki konsolidacyjnej różnych organizacji i struktur, prowadzonej przez ówczesne władze Rzeczypospolitej Polskiej i partię komunistyczną, czego najbardziej widocznym przejawem było połączenie w grudniu 1948 roku Polskiej Partii Robotniczej i Polskiej Partii Socjalistycznej w Polską Zjednoczoną Partię Robotniczą (dalej: PZPR). Przed powstaniem ZBoWiD-u na terenie kraju istniały następujące organizacje kombatanckie: Związek Bojowników z Faszyzmem i Najazdem Hitlerowskim o Niepodległość i Demokrację (do 1948 roku funkcjonował jako Związek Uczestników Walki Zbrojnej o Niepodległość i Demokrację oraz Związek Osadników Wojskowych), Polski Związek Byłych Więźniów Politycznych Hitlerowskich Więzień i Obozów Koncentracyjnych, Związek Dąbrowszczaków (Polaków, którzy w latach 1936-1939 brali udział w walce u boku sił republikańskich w Hiszpanii w ramach tzw. Brygad Międzynarodowych, występując przeciwko obozowi nacjonalistycznemu skupionemu wokół gen. Francisca

* Artykuł został opracowany na podstawie pracy dyplomowej pt. „Akta Zarządu Wojewódzkiego Związku Bojowników o Wolność i Demokrację w Lublinie 1949-1979. Zawartość i problematyka opracowania" napisanej na Podyplomowym Studium Archiwistyki w Instytucie Historii Uniwersytetu Marii Curie-Skłodowskiej w Lublinie pod kierunkiem dr. hab. Janusza Łosowskiego i obronionej 7 lipca 2007.

${ }^{1}$ Zaprezentowany poniżej zarys historii i organizacji ZBoWiD, mimo że wykracza poza tematykę artykułu, został zamieszczony z uwagi na nieopracowanie do chwili obecnej rysu historycznego Zarządu Wojewódzkiego ZBoWiD w Lublinie. 
Franco), Związek Weteranów Walk Rewolucyjnych 1905-1918 (skupiający Polaków, którzy uczestniczyli w walce z caratem, począwszy od rewolucji 1905 roku aż do wydarzeń związanych z rewolucją październikową w dniach 6-7 listopada 1917 roku i wojną domową w Rosji pomiędzy siłami bolszewickimi a zwolennikami caratu, czyli tzw. białogwardzistami i wspierającymi ich siłami interwencyjnymi państw europejskich, Stanów Zjednoczonych i Japonii), Związek Weteranów Powstań Śląskich, Związek Powstańców Wielkopolskich, Związek Żydów Byłych Uczestników Walki Zbrojnej z Faszyzmem, Związek Obrońców Westerplatte, Związek Czerwonych Kosynierów, Związek Obrońców Wybrzeża, Stowarzyszenie Byłych Więźniów Twierdzy Zakroczymskiej². Podstawą prawną funkcjonowania ZBoWiD-u było rozporządzenie Prezydenta Rzeczypospolitej z 27 października 1932 - prawo o stowarzyszeniach z późniejszymi zmianami ${ }^{3}$. Cele Związku (zgodnie z § 7-9 statutu ZBoWiD-u, uchwalonego zarządzeniem Ministra Spraw Wewnętrznych z 7 lutego 1970) były następujące: pogłębianie wśród członków uczuć socjalistycznego patriotyzmu, wierności ludowej Ojczyźnie oraz wychowywanie ich w duchu międzynarodowej solidarności z ludźmi innych narodów walczącymi o pokój, demokrację oraz narodowe i społeczne wyzwolenie, współdziałanie z politycznymi i społecznymi organizacjami Frontu Jedności Narodu (dalej: FJN) oraz instytucjami państwowymi w dziele socjalistycznej budowy kraju, wzmacniania jego obronności i pozycji na forum międzynarodowym, popularyzowanie postępowych i patriotycznych tradycji walk narodowo-wyzwoleńczych, zbieranie materiałów dotyczących historii walk o wolność i demokrację, ochrona pamiątek i miejsc związanych z walką i męczeństwem narodu, roztaczanie opieki nad członkami Związku, ich rodzinami oraz rodzinami po zmarłych członkach, a także po poległych i pomordowanych bojownikach o wolność i demokrację. Cele realizowano przez prowadzenie działalności propagującej problematykę i zadania Związku za pośrednictwem środków masowego przekazu (prasa, radio, telewizja, film, wydawnictwa, odczyty, wystawy), organizowanie zebrań członkowskich poświęconych omawianiu i organizowaniu działalności Związku w zakresie spraw politycznych, historycznych, kulturalnych, socjalnych i gospodarczych, współdziałanie z pokrewnymi organizacjami krajowymi i zagranicznymi dla obrony pokoju i demokracji. Władze centralne ZBoWiD-u w Warszawie tworzyły: Krajowy Kongres, Rada Naczelna, Zarząd Główny, Główna Komisja Rewizyjna i Główny Sąd Koleżeński ${ }^{4}$. ZBoWiD wchodził w skład międzynarodowej organizacji kombatanckiej Fédération Internationale des Résistants (dalej: FIR), działającej od 1951 roku w Wiedniu, obecnie zaś w Berlinie. Organem prasowym

\footnotetext{
${ }^{2}$ ZBoWiD-owcy. Tradycje i zadania, red. M. Łomacki, J. Szulc-Łyskowa, Warszawa 1969, s. 391.

${ }^{3}$ Moc prawną utraciło z chwilą wejścia w życie ustawy z 7 kwietnia 1989 - prawo o stowarzyszeniach. Zob.: Dziennik Ustaw Rzeczypospolitej Polskiej 1932 Nr 94, poz. 808; 1946 Nr 4, poz. 30; Dziennik Ustaw Polskiej Rzeczypospolitej Ludowej (dalej: Dz. U. PRL) 1949 Nr 41, poz. 293; 1949 $\mathrm{Nr} 45$, poz. $335 ; 1950 \mathrm{Nr} 44$, poz. 401; $1950 \mathrm{Nr} 53$, poz. $489 ; 1964 \mathrm{Nr} 41$, poz. $276 ; 1985 \mathrm{Nr} 36$, poz. 167 ; $1989 \mathrm{Nr} 20$, poz. 104.

${ }^{4}$ Monitor Polski, 1970 Nr 6, poz. 57.
} 
Związku było pismo „Za Wolność i Lud”. Na mocy rozporządzenia Rady Ministrów z 15 lipca 1969 ZBoWiD został uznany za „stowarzyszenie wyższej użyteczności”. Działalność ZBoWiD-u zakończyła się jego rozwiązaniem wraz z końcem Polskiej Rzeczypospolitej Ludowej w 1990 roku. Na bazie istniejących struktur utworzono w kwietniu 1990 roku Związek Kombatantów Rzeczypospolitej Polskiej i Byłych Więźniów Politycznych ${ }^{6}$.

Na terenie województwa lubelskiego z wymienionych powyżej organizacji kombatanckich poprzedzających powstanie ZBoWiD-u istniały: Związek Bojowników z Faszyzmem i Najazdem Hitlerowskim o Niepodległość i Demokrację (powstał pod koniec 1945 roku, w dniach 21-22 października 1945 obradował bowiem w Lublinie I Zjazd Wojewódzki, na którym wybrano lokalne władze) $)^{7}$, Polski Związek Byłych Więźniów Politycznych Hitlerowskich Więzień i Obozów Koncentracyjnych oraz Związek Weteranów Walk Rewolucyjnych 1905-1918 (powołany w dniach 15-16 sierpnia 1945 mocą uchwały IX Ogólnokrajowego Zjazdu Delegatów Stowarzyszeń Byłych Więźniów Politycznych z okresu walk rewolucyjnych 1905-1918 obradującego w Łodzi) ${ }^{8}$. Były to najważniejsze, ale naturalnie nie jedyne związki kombatanckie na tym terenie'. Powstały w 1949 roku Zarząd Okręgu ZBoWiD (od 1975

${ }^{5}$ Dz. U. PRL 1969 Nr 21, poz. 153.

${ }^{6} \mathrm{~W}$ województwie lubelskim nowa organizacja została zarejestrowana przed kwietniem 1991 roku, o czym informował Wydział Spraw Obywatelskich Urzędu Wojewódzkiego w Lublinie Zarząd Oddziału Polskiego Związku Kombatantów w Białymstoku pismem z 17 kwietnia 1991. Zob.: Archiwum Państwowe w Lublinie (dalej: APL), 1079 Urząd Wojewódzki w Lublinie, spis 5: Wydział Spraw Wewnętrznych, poz. 11 Nadzór nad stowarzyszeniami, k. 51.

7 Tamże, 720 Związek Bojowników o Wolność i Demokrację Zarząd Wojewódzki w Lublinie, sygn. 375 Księga personalna pracowników b. Zarządu Okręgu i Zarządu Oddziału Pow. ZBoWiD $w$ Lublinie, k. 1-24, 29-32, 35-36, 41-44, 47-50, 53-56, 59-60, 63-64, 67-70, 147-150; 1233 Komitet Wojewódzki Polskiej Partii Robotniczej w Lublinie, sygn. 183 Zwiazek Inwalidów Wojennych RP [Polski Związek Byłych Więźniów Politycznych, Związek Uczestników Walki Zbrojnej o Niepodległość i Demokrację: protokoły i sprawozdania z zebrań, plany pracy, korespondencja], k. 70, 76-87.

${ }^{8}$ Związek został wpisany do rejestru stowarzyszeń Zarządu Miejskiego w Łodzi na podstawie decyzji Prezydenta Miasta Łodzi z 13 marca 1946. W Lublinie rejestracja nastąpiła 28 czerwca 1946, po czym Związek wpisano w tomie trzecim rejestru stowarzyszeń Zarządu Miejskiego w Lublinie pod nr 11. Zob.: tamże, 698 Urząd Wojewódzki Lubelski, Wydział Społeczno-Polityczny, sygn. 393 Stowarzyszenia niezarejestrowane - „Stowarzyszenie byłych więźniów Politycznych” Oddziat w Lublinie, k. 41-43; sygn. 423 Zawiadomienia Prezydenta m. Lublina o założonych i zgłoszonych stowarzyszeniach, k. 13.

${ }^{9} \mathrm{~W}$ omawianym okresie na terenie województwa lubelskiego kształtowały się i funkcjonowały również inne organizacje o charakterze kombatanckim, m.in. Związek Byłych Więźniów Ideowo-Politycznych z czasów wojny 1939-1945, Stowarzyszenie Byłych Więźniów Politycznych oraz Związek Inwalidów Wojennych Rzeczypospolitej Polskiej (późniejszy Związek Inwalidów Wojennych Polskiej Rzeczypospolitej Ludowej). W Tomaszowie Lubelskim na początku 1946 roku zawiązał się Związek Demokratyczny Uczestników Walk o Niepodległość, brak jednak potwierdzenia, czy był on lokalnym odłamem Związku Bojowników z Faszyzmem i Najazdem Hitlerowskim o Niepodległość i Demokrację, czy też zupełnie odrębnym tworem. Wyjaśnienie tej kwestii byłoby możliwe po dokładnym przeanalizowaniu rejestrów stowarzyszeń Zarządu Miejskiego w Lublinie z tego okresu. Zob.: tamże, sygn. 393 Stowarzyszenia niezarejestrowane - ,, Stowarzyszenie bylych więźniów Politycznych” Oddziat w Lublinie, k. 1-26, 28, 30, 33-39; sygn. 418 Korespondencja $w$ sprawach stowarzyszeń $i$ zwiazków, Pismo Starosty Powiatowego Włodawskiego do Wydziału Społeczno-Politycznego Urzędu 
roku w związku z wejściem w życie ustawy o dwustopniowym podziale administracyjnym państwa oraz o zmianie ustawy o radach narodowych z 28 maja 1975 przemianowany na Zarząd Wojewódzki) funkcjonował do 1990 roku $^{10}$. Władze tworzyły: Zjazd Delegatów Okręgu, Zarząd Okręgu, Okręgowa Komisja Rewizyjna i Okręgowy Sąd Koleżeński ${ }^{11}$. Przy Zarządzie Wojewódzkim ZBoWiD w Lublinie działało kilka klubów środowiskowych, takich jak: Klub Uczestników Walk Rewolucyjnych 1905 roku, Klub Uczestników Powstań Śląskich, Klub Byłych Więźniów Obozów Koncentracyjnych (Sachsenhausen, Majdanka, Oświęcimia, Buchenwaldu), Klub Byłych Więźniów Politycznych Zamku i „Pod Zegarem” w Lublinie (ten ostatni funkcjonował jeszcze po rozwiązaniu ZBoWiD-u i zakończył działalność w 2003 roku) ${ }^{12}$. Zarządowi podlegały oddziały powiatowe w liczbie $20^{13}$ oraz stale

Wojewódzkiego Lubelskiego z 17 VIII 1946, Pismo Wydziału Społeczno-Politycznego Urzędu Wojewódzkiego Lubelskiego do Zarządu Oddziału Polskiego Związku Byłych Więźniów Politycznych Hitlerowskich Więzień i Obozów z 3 I 1947, Pismo Starosty Powiatowego Włodawskiego do Wydziału Społeczno-Politycznego Urzędu Wojewódzkiego Lubelskiego z 4 II 1947; sygn. 422 Zawiadomienie Starostów Powiatowych o zgloszonych i założonych stowarzyszeniach $i$ zwiąkach na terenie powiatu, k. 51, 54, 71; sygn. 423 Zawiadomienia Prezydenta m. Lublina o założonych i zgloszonych stowarzyszeniach, k. 12; 701 Wojewódzki Urząd Informacji i Propagandy w Lublinie, sygn. 49 Wspótpraca ze Zwiazkiem Uczestników Walk o Niepodległość i Demokrację, k. 1-3.

${ }^{10}$ Dz. U. PRL 1975 Nr 16, poz. 91. Zob. też: APL, 720 Związek Bojowników o Wolność i Demokrację Zarząd Wojewódzki w Lublinie, sygn. 30 Protokóty z posiedzeń Prezydium Zarządu Okręgu ZBoWiD w Lublinie, Protokół nr 3 z posiedzenia Prezydium Zarządu Okręgu ZBoWiD w Lublinie odbytego w dniu 12 IX 1975.

${ }^{11}$ Monitor Polski, 1970 Nr 6, poz. 57.

${ }^{12}$ W latach 50. przez pewien okres działała także Komisja Księży, uczestników ruchu oporu. Postulat wysunięty przez środowisko „synów pułku” w sprawie stworzenia swojego klubu został w 1972 roku odrzucony, jednak w okresie późniejszym zezwolono na jego utworzenie. Zob.: APL, sygn. 46 Protokóty z posiedzeń Prezydium Zarząu Okręgu ZBoWiD w Lublinie, Protokół nr 2/72 z posiedzenia Prezydium Zarządu Okręgu ZBoWiD w Lublinie odbytego w dniu 7 VI 1972; sygn. 151 Informacje Zarządu Oddz. Miej. ZBoWiD, k. 44-70; sygn. 352 Sprawozdania i protokóly z posiedzeń Prezydium b. Zarządu Oddziału Miejskiego ZBoWiD w Lublinie, Protokół z koleżeńskiego zjazdu członków klubu Sachsenhausen przy Zarządzie Okręgu ZBoWiD w Lublinie odbytego w dniu 9 V 1971; sygn. 369 Książka protokółów posiedzeń byłego Zarzadu Okręgu ZBoWiD w Lublinie, k. 1-12.

${ }_{13}$ Oddziały zostały zlikwidowane w okresie wrzesień-październik 1975 roku w związku z wejściem w życie ustawy o dwustopniowym podziale admnistracyjnym państwa oraz o zmianie ustawy o radach narodowych z 28 maja 1975. W tym samym roku obszar podlegający Zarządowi Wojewódzkiemu ZBoWiD w Lublinie znacznie się zmniejszył (obejmował dawne oddziały: Bełżyce, Bychawa, Kraśnik, Lubartów, Lublin miasto, Lublin powiat, Opole Lubelskie i Puławy) wobec utworzenia trzech Zarządów Wojewódzkich w nowych województwach: bialskopodlaskim (objęło tereny oddziałów: Biała Podlaska, Parczew i Radzyń Podlaski), chełmskim (Chełm, Krasnystaw, Włodawa) i zamojskim (Biłgoraj, Hrubieszów, Tomaszów Lubelski, Zamość). Dodatkowo część terenu byłego Oddziału ZBoWiD w Łukowie podlegała od tej pory Zarządowi Wojewódzkiemu w Siedlcach, zaś Oddziału ZBoWiD w Janowie Lubelskim Zarządowi Wojewódzkiemu w Tarnobrzegu. Likwidację przeprowadzano poprzez zwołanie plenarnego posiedzenia Oddziału i powołanie Komisji do spraw Przekazania Agend Oddziału ZBoWiD do Zarządu Wojewódzkiego ZBoWiD zgodnie z instrukcją Zarządu Głównego z 12 sierpnia 1975. W wyniku zmian Zarządowi Wojewódzkiemu ZBoWiD w Lublinie podlegały jedynie koła terenowe, które zgrupowano w sześciu rejonach: I. Lublin miasto, II. Lublin powiat, III. Puławy, IV. Kraśnik, V. Opole Lubelskie, VI. Lubartów. Zob.: tamże, sygn. 25 Protokóły z narad prezesów Zarządu, Oddziałów i Okręgu ZBoWiD w Lublinie, k. 22-27; sygn. 31 Protokóły z posiedzeń Prezydium Zarządu Okręgu ZBoWiD w Lublinie, Protokół nr 2/77 z posiedzenia Prezydium Zarządu 
zmieniająca się liczba kół (terenowych w gminach lub gromadach, dzielnicowych lub miejskich w większych miastach, zakładowych na terenie większych zakładów przemysłowych, przedsiębiorstw lub instytucji, takich jak urzędy czy komendy Milicji Obywatelskiej) - w latach 1949-1950 było ich 38, w 1951 - 75, w 1969 281, w 1978 - 104 (22 miejskie, 59 gminnych, 5 miejsko-gminnych, 4 terenowe i 14 zakładowych). Liczba członków wahała się od 20016 w 1969 roku do 15745 w 1978 roku $^{14}$.

\section{Personel kancelarii i jego obowiązki}

Zakres pracy personelu kancelaryjnego poszczególnych komórek ZBoWiD-u regulowały opracowywane przez Sekretariat Zarządu Głównego i wydawane przez Zarząd Główny regulaminy pracy biur, przy czym najbardziej szczegółowy i obowiązujący w tym okresie był ramowy regulamin pracy biur i sekretarzy technicznych zarządów oddziałów ZBoWiD-u z 1 lipca 1967 roku. Z kolei Zarząd Wojewódzki w 1963 roku opracował na potrzeby własne regulamin pracy pracowników biura. Zawierał on wytyczne w sprawie urządzenia i pracy samych lokali biurowych, predyspozycji, zakresu obowiązków i stopnia podległości zatrudnionych w nich pracowników oraz przysługujących im praw pracowniczych. Poszczególne okręgi, oddziały, a nawet same koła terenowe, w oparciu o regulaminy, regulowały wspomniane kwestie we własnym zakresie, opracowując aktualizowane w razie potrzeby podziały i wykazy czynności poszczególnych członków Zarządu. Każdy z nich otrzymywał powierzony mu odcinek pracy, za który był odpowiedzialny ${ }^{15}$.

Wojewódzkiego ZBoWiD w Lublinie odbytego w dniu 21 III 1977; sygn. 38 Protokóty z posiedzeń, uchwały, rezolucje b. Zarząu Okręgu ZBoWiD w Lublinie, Pisma Zarządu Wojewódzkiego ZBoWiD w Lublinie do I sekretarzy KW PZPR w Białej Podlaskiej, Chełmie i Zamościu z dnia 16 VI 1975, Dane dotyczące nowo utworzonych województw bialskopodlaskiego, chełmskiego, lubelskiego i zamojskiego (ilość członków i kół) oraz wykaz miejscowości odchodzących do województwa tarnobrzeskiego [z 1975 roku], Pisma Zarządu Wojewódzkiego ZBoWiD w Lublinie do Zarządu Głównego ZBoWiD z dnia 15 VII 1975, Plan zabezpieczenia realizacji uchwały Prezydium Zarządu Głównego ZBoWiD z dnia 3 VII 1975 o wprowadzeniu dwustopniowej struktury organizacyjnej ZBoWiD dostosowanej do podziału administracyjnego kraju i ustaleń Sekretariatu Zarządu Głównego ZBoWiD z dnia 12 VIII 1975 dla Zarządu Wojewódzkiego ZBoWiD w Lublinie.

${ }^{14}$ APL, 720 Związek Bojowników o Wolność i Demokrację Zarząd Wojewódzki w Lublinie, sygn. 63 Sprawozdanie statystyczne z działalności Zarzadu Woj. ZBoWiD w Lublinie, Sprawozdanie statystyczne z rocznej działalności Zarządu Wojewódzkiego ZBoWiD w Lublinie za okres od 1 I 1978 do 31 XII 1978; sygn. 226 Protokóty z posiedzeń Prezydium Zarządu Okręgu ZBoWiD w Lublinie, Protokół nr 9 z posiedzenia Prezydium Zarządu Okręgu ZBoWiD w Lublinie odbytego w dniu 31 XII 1970; sygn. 231 Materiaty V Zjazdu Okręgowego ZBoWiD w Lublinie w dn. 27.4.70, Sprawozdanie na V Okręgowy Zjazd Sprawozdawczo-wyborczy Delegatów za okres od IV 1964 do XII 1969; sygn. 369 Książka protokólów posiedzeń byłego Zarzadu Okręgu ZBoWiD w Lublinie, k. 68-77; sygn. 370 Ksiązka protokółów posiedzeń bylego Zarządu Okręgu ZBoWiD w Lublinie, k. 41-45.

${ }^{15} \mathrm{Na}$ przykład w 1966 roku podział pracy w Zarządzie Oddziału Miejskiego ZBoWiD w Lublinie był następujący: reprezentacja związku, czuwanie nad całością pracy (prezes Zdzisław Wiśniewski), kierowanie pracą biura, nadzór nad całością pracy kół, współpraca z Prezydium Miejskiej Rady 
Prezes Zarządu Okręgu, Oddziału czy też Koła zwykle był osobą reprezentującą ZBoWiD na zewnątrz i czuwającą nad całokształtem pracy. Wiceprezesom z kolei powierzano kierowanie pracami poszczególnych komisji problemowych oraz sprawy współpracy z innymi organizacjami, podobnie jak zwykłym członkom Zarządu. Kompetencje skarbnika obejmowały sprawy finansowe i gospodarcze. Biuro podlegało nadzorowi Prezydium Zarządu, zaś jego pracą i prowadzeniem dokumentacji kierował w większości przypadków sekretarz Zarządu (do jego kompetencji należało: prowadzenie dokumentacji finansowo-księgowej, wydawanie znaczków członkowskich, odznak związkowych za opłatą, przedłużanie legitymacji leczniczych, wydawanie wszelkich druków odpłatnych i statutów oraz inne sprawy finansowe, załatwianie spraw biurowych $\mathrm{w}$ razie potrzeby, w wolnym czasie branie udziału w zebraniach) przy pomocy oddelegowanego do pomocy pracownika, tzw. sekretarza technicznego, który zajmował się: całością pracy sekretariatu, załatwianiem korespondecji i spraw interesantów, spraw związanych z przyjęciem do Związku, przyjęciem wniosków o odznaczenia, zapomogi i renty, udziałem w posiedzeniach Prezydium i komisji oraz przygotowywaniem dla tych gremiów materiałów, a także wszystkimi innymi sprawami związanymi ze swoją pracą. Sekretarz techniczny brał również udział w zebraniach, w zależności od możliwości czasowych. Obydwu obowiązywała znajomość statutu ZBoWiD-u, przepisów odnoszących się do organizacji i zakresu działania Związku, organizacji biura, podziałów czynności określonych regulaminem, instrukcji kancelaryjnej i sposobów przechowywania akt oraz innych przepisów prawnych niezbędnych do wykonywania obowiązków służbowych. Sekretarz jako kierownik biura miał obowiązek opracować szczegółowy

\footnotetext{
Narodowej i Miejskim Komitetem FJN (wiceprezes Zdzisław Nadulski), kierowanie pracą Komisji Socjalno-Bytowej i Rent (wiceprezes Józef Radajewski), kierowanie pracą Komisji Propagandowo-Historycznej i Młodzieżowej, współpraca z LOK i ZMS (wiceprezes Czesław Zarębski), kierowanie pracą Komisji Weryfikacyjno-Odznaczeniowej i współpraca z 7 Kołobrzeskim Pułkiem Piechoty (wiceprezes Marian Krawczyk), prowadzenie dokumentacji Zarządu (sekretarz Stefan Rodak), pomoc sekretarzowi, współpraca ze stronnictwami politycznymi i Ligą Kobiet (zastępca sekretarza Kazimierz Kowalski), prowadzenie spraw finansowych i gospodarczych (skarbnik Kazimierz Ciężczyk), kierowanie pracą Komisji Zdrowia i Porad Prawnych, współpraca ze Związkiem Studentów Polskich i ZHP (członek Zarządu Gabriel Brzęk). Zob.: tamże, sygn. 103 Protokóty z posiedzeń Prezydium Zarz. Miejskiego ZBoWiD w Lublinie, Organizacyjny podział pracy między członków Prezydium Oddziału Miejskiego ZBoWiD w Lublinie [z 1966 roku]; sygn. 115 Protokóty z posiedzeń Zarzadu Oddziatu Miejskiego ZBoWiD w Lublinie, Organizacyjny podział pracy między członków Prezydium Oddziału Miejskiego ZBoWiD w Lublinie [z 1966 roku]. Podobne podziały obowiązków sporządzały na swoje potrzeby inne oddziały i koła ZBoWiD. Zob.: tamże, sygn. 107 Protokóty zebrań Kót ZBoWiD, Protokół nr 79 z posiedzenia Zarządu Koła Osiedlowego VII „Kośminek” w Lublinie odbytego w dniu 11 IV 1975; sygn. 111 Protokóty zebrań Koła ZBoWiD przy KWMO w Lublinie, Podział pracy i zakresu odpowiedzialności członków Zarządu Zakładowego Koła ZBoWiD przy KWMO w Lublinie [z 1969 roku]; sygn. 124 Protokóty z zebrań Koła ZBoWiD nr 2, Protokół nr 2 z posiedzenia Zarządu Koła Dzielnicowego nr 2 ZBoWiD w Lublinie odbytego w dniu 2 II 1968; sygn. 170 Protokóły i informacje b. Zarządu Oddziału Miejskiego ZBoWiD, Zakres czynności urzędującego wiceprezesa Oddziału Miejskiego ZBoWiD w Lublinie tow. Tadeusza Patyńskiego; sygn. 349 Protokóty z posiedzeń Prezydium oraz sprawozdanie z działalności b. Zarzadu Oddziału Miejskiego ZBoWiD w Lublinie, Protokół z posiedzenia Zarządu Oddziału Miejskiego ZBoWiD w Lublinie odbytego w dniu 19 IX 1968.
} 
zakres czynności dla pracowników biura, ponosić pełną odpowiedzialność za ich pracę i jej wydajność, opracować miesięczny plan czynności zaakceptowany przez prezesa oddziału, uwzględniający wszystkie problemowe zagadnienia obsługiwane przez biuro (np. Zarząd Oddziału Miejskiego ZBoWiD w Lublinie otrzymał zalecenie opracowania takiego regulaminu wewnętrznego biura i zakresu czynności na podstawie uchwały Komitetu Miejskiego PZPR z 15 maja 1968) ${ }^{16}$. Dla sekretarzy technicznych organizowano w Zarządzie Okręgu systematyczne szkolenia, na których zapoznawano ich z ogólnymi zasadami pracy biura, trybem postępowania $\mathrm{z}$ dokumentacją oraz przepisami prawnymi, pomocnymi w załatwianiu spraw członkowskich różnych kategorii ${ }^{17}$. Zatrudniano ich na pełnym lub niepełnym etacie

${ }^{16}$ Tamże, sygn. 151 Informacje Zarządu Oddz. Miej. ZBoWiD, k. 85-86.

17 Tamże, sygn. 115 Protokóły z posiedzeń Zarządu Oddziału Miejskiego ZBoWiD w Lublinie, Organizacyjny podział pracy między członków Prezydium Oddziału Miejskiego ZBoWiD w Lublinie [z 1966 roku]; sygn. 144, Materiaty Zespołu Partyjnego b. Zarzadu Oddziału Miejskiego ZBoWiD w Lublinie, Komunikat informacyjny nr 1/74 dla członków Zarządu O.M. ZBoWiD i prezesów kół z 30 I 1974; sygn. 161 Protokóty z posiedzeń Prezydium Zarz. Oddziału Miejskiego ZBoWiD w Lublinie; sygn. 286 Protokóty z plenarnych zebrań, posiedzeń i działalności b. Zarzadu Oddziału Pow. ZBoWiD w Chełmie oraz kwestionariusze członka władz i aktywu ZBOWiD, Protokół z kontroli działalności Zarządu Oddziału Powiatowego ZBoWiD w Chełmie dokonanej w dniu 19 II 1966; sygn. 298 Protokóły $z$ posiedzén Prezydium rozszerzonych plenarnych posiedzeń i sprawozdanie Prezydium $b$. Zarzadu Oddziału Pow. ZBoWiD w Zamościu, Protokół nr 6/3/69 z odbytego posiedzenia Prezydium Zarządu Oddziału Powiatowego ZBoWiD w Zamościu w dniu 21 VI 1969; sygn. 303 Protokóty z posiedzeń Prezydium, plan pracy na 1974 r. i sprawozdania z działalności b. Zarządu Oddziału Pow. ZBoWiD w Zamościu, Protokół nr 8/74 z odbytego posiedzenia Prezydium Zarządu Oddziału Powiatowego ZBoWiD w Zamościu w dniu 12 VI 1974; sygn. 306 Sprawy organizacyjne, protokóly z posiedzeń Prezydium, dokumentacja sprawozdawczo-wyborcza b. Zarzadu Oddziału Pow. ZBoWiD w Puławach, Sprawozdanie organizacyjne Zarządu Oddziału ZBoWiD w Puławach za kwartał od dnia 1 X 1960 do dnia 31 XII 1960; sygn. 312 Protokóły z posiedzeń Prezydium, walnych zebrań sprawozdawczo-wyborczych, sprawozdania z działalności Kół terenowych b. Zarządu Oddziału Pow. ZBoWiD w Puławach, Protokół nr 7/73 z posiedzenia Prezydium Zarządu Powiatowego ZBoWiD w Puławach odbytego w dniu 8 VI 1973; sygn. 313 Protokóty z posiedzeń Prezydium, plenarnych posiedzeń i sprawozdania z działalności Zarzadu Oddziału Pow. ZBoWiD w Puławach, Protokół nr 25 z posiedzenia Prezydium Zarządu Oddziału Powiatowego [ZBoWiD w Puławach] odbytego w dniu 8 X 1974; sygn. 314 Sprawozdania z posiedzeń, narady Prezesów kól terenowych, protokóly z plenarnych posiedzeń i inne materiały z działalności Zarzadu Oddziału Pow. ZBoWiD w Puławach, Protokół z posiedzenia Prezydium Zarządu Oddziału ZBoWiD w Puławach odbytego w dniu 18 I 1975; sygn. 318 Protokóły ze zjazdów, plenarnych zebrań i posiedzeń Prezydium i działalności b. Zarzadu Oddziału Pow. ZBoWiD w Łukowie, Protokół nr 4/69 z posiedzenia Prezydium Zarządu Oddziału ZBoWiD w Łukowie odbytego w dniu 19 IV 1969; sygn. 321 Sprawozdanie na VII zjazd Zwyczajny, plany pracy, protokóły z posiedzeń oraz sprawozdania z działalności b. Zarzadu Oddziału Pow. ZBoWiD w Parczewie, Sprawozdanie [Zarządu Oddziału Powiatowego ZBoWiD w Parczewie] na VII Zjazd zwyczajny z X 1971; sygn. 335 Wykazy kót terenowych, protokóty z plenarnych posiedzeń Prezydium, sprawozdania komisji rewizyjnej oraz materiaty VII Zjazdu b. Zarzadu Oddziału Pow. ZBoWiD w Kraśniku, Sprawozdanie Komisji Rewizyjnej przy Oddziale Powiatowym ZBoWiD w Kraśniku z przeprowadzonej kontroli działalności Zarządu za okres od 1 I 1969 do 31 V 1971; sygn. 355 Plany pracy, protokóły z posiedzeń Prezydium oraz kwestionariusze członka władz i aktywu ZBoWiD b. Zarzadu Oddziału Pow. w Lublinie, Pismo Zarządu Okręgu ZBoWiD do Zarządu Oddziału Powiatowego ZBoWiD w Lublinie z 29 XII 1967; sygn. 359 Protokóły z posiedzeń Prezydium Zarządu i terenowych kól b. Zarządu Oddziału Pow. ZBoWiD w Lublinie, Protokół nr 8 z posiedzenia Prezydium Zarządu Oddziału Powiatowego ZBoWiD w Lublinie z dnia 31 X 1974; sygn. 363 Sprawozdania z odbytych zebrań, dokumentacja sprawozdawczo-wyborcza oraz 
i opłacano z funduszu bezosobowego, w niektórych przypadkach (np. w oddziałach ZBoWiD-u w Hrubieszowie i Radzyniu Podlaskim) osoby te pracowały społecz$n^{18}{ }^{18}$. Wymogi formalne względem personelu kancelaryjnego nie były ściśle określone w instrukcjach, zwłaszcza odnośnie do niższych szczebli organizacyjnych, gdy nie dysponowano nadmiarem personelu. Zarząd Okręgu pod koniec 1959 roku opracował projekt tego rodzaju wymogów, stawiając przed kierownikiem biura (sekretarzem) obowiązek posiadania ukończonych studiów wyższych, przy czym preferowano wykształcenie historyczne. Oczywiście musiał on być albo członkiem Zarządu albo aktywistą z odpowiednim stażem organizacyjnym i doświadczeniem. Wymienieni stanowili całość personelu kancelarii, uzupełnianego w razie potrzeby o zatrudniane maszynistki (zwykle na podstawie umowy o dzieło lub na niepełnym etacie wskutek dysponowania jedynie skromnymi sumami na to przedsięwzięcie). Kryteria, które musiały one spełniać zgodnie ze wspomnianym powyżej projektem, były zrozumiałe: znajomość stenografii oraz biegłe posługiwanie się dwoma najbardziej rozpowszechnionymi i spotykanymi w pracy kancelaryjnej Związku językami obcymi: rosyjskim i niemieckim ${ }^{19}$. Stopniowe zwiększanie obsady personalnej spowodowane było stale rosnącą ilością spraw załatwianych przez biura Związku. W latach 1965-1969 całokształt działalności kancelaryjnej Zarządu Wojewódzkiego w zakresie korespondencji przychodzącej i wychodzącej (ilość pism) wyglądał następująco: w 1965 roku - 950 i 903, w 1966 - 2050 i 2032, w $1967-3483$ i 3668, w 1968 - 3805 i 3975, w $1969-4152$ i 43912. Z kolei w Oddziale ZBoWiD w Parczewie w 1968 roku załatwiono 796 interesantów, w 1971 - 2163, w 1968 roku wydano 75 zaświadczeń, w 1971 - 330. We wspomnianych latach zaświadczeń do szkół wydano odpowiednio 12 i 96, interwencji w urzędach było 8 i 47, interwencji w sprawie mieszkań 2 i 8, w sprawie odznaczeń 10 i 28. Oceniając sytuację biura Zarządu Oddziału Powiatowego ZBoWiD w Lublinie na posiedzeniu Prezydium 31 października 1974, członek Zarządu Czesław Kondrat stwierdził, „że pomimo poprawy obiegu dokumentów i szybszego załatwiania spraw praca jednej osoby nie przyniesie dobrych rezultatów, gdyż trzeba zająć się sprawami kół terenowych" i w związku z tym postawił wniosek o zatrudnienie od 1 listopada dodatkowej osoby jako sekretarza technicznego. Propozycje takie z uwagi na wspomniane wyżej ograniczenia finansowe rzadko znajdowały aprobatę, w związku z tym posiłkowano się rozwiązaniami doraźnymi, angażując do pracy innych członków Zarządu, zlecając

sprawozdania z działalności b. Zarzqdu Oddziału Pow. ZBoWiD w Hrubieszowie, Plan działalności Powiatowego Zarządu Oddziału ZBoWiD na rok 1965.

${ }^{18}$ Z. J. Hirsz, Lubelska organizacja ZBoWiD w latach 1964-1969, Lublin 1969, s. 103.

${ }^{19}$ APL, 720 Związek Bojowników o Wolność i Demokrację Zarząd Wojewódzki w Lublinie, sygn. 93 Sprawy organizacyjne b. Zarzadu Okręgu ZBoWiD w Lublinie, Projekt obsady osobowej i preliminarza wydatków administracyjnych Zarządu Okręgu ZBoWiD w Lublinie [z 1959 roku].

${ }^{20}$ Tamże, sygn. 224 Protokóty z posiedzeń Prezydium Zarządu Okręgu ZBoWiD w Lublinie, Sprawozdanie z działalności Zarządu Okręgu ZBoWiD w Lublinie za okres od 19 IV 1964 do 31 XII 1969 na Przedkongresową Okręgową Konferencję Delegatów. Por.: Z. J. Hirsz, Lubelska organizacja ZBoWiD, s. 102. 
prace biurowe podmiotom nienależącym do Związku (na zasadzie umowy-zlecenia) lub ostatecznie wykorzystując dla wynagrodzenia pracowników kancelarii środki budżetowe na to nieprzewidziane. W celu podniesienia wydajności pracy lub wyróżnienia szczególnie aktywnych pracowników przyznawano okresowo nagrody za dobre wyniki w pracy i działalność społeczną (wielokrotnie wskutek dużej ilości pracy biurowej kancelaria Związku pracowała w dni wolne od pracy i po godzinach ${ }^{21}$.

\section{Stosowane systemy kancelaryjne, instrukcje i wykazy akt}

W Zarządzie Wojewódzkim ZBoWiD i podlegających mu komórkach nie wypracowano sposobu na stosowanie jednego, ujednoliconego systemu kancelaryjnego. $\mathrm{W}$ tej dziedzinie obowiązywała raczej dowolność, nieskrępowana narzuconymi z góry przepisami z uwagi na brak do 1979 roku opracowanego i zaleconego do stosowania odgórnie wykazu akt i instrukcji kancelaryjnych. Zgodnie z protokołami wizytacji składnicy akt Zarządu Wojewódzkiego w początkowym okresie po jego odtworzeniu w 1956 roku stosowano system dziennikowy, natomiast już w 1958 roku stwierdzono występowanie systemu bezdziennikowego z rejestrem wpływów pism, księgą pocztową, księgą doręczeń i wypracowanym wewnętrznie rzeczowym podziałem akt na: sprawy społeczno-polityczne (obejmujące korespondencję z partią, z Komitetem Wojewódzkim ZSL, ze szkołami w sprawach o patronat, pomoc w budownictwie itd.), sprawy organizacyjne (podzielone na 20 teczek, z czego teczka spraw ogólnych zawierała załatwione sprawy z ministerstwami i Zarządem Głównym, 19 subteczek podzielonych było według powiatów, z tych każda gromadziła akta swego powiatu, takie jak protokoły zebrań, sprawozdania z działalności itd.), korespondencja w sprawach finansowych, weryfikacji członków i odznaczeń, akta dotyczące historycznych obchodów, akta rent i pomocy społecznej, akta komisji rewizyjnej, akta sądu koleżeńskiego. Podział ten w okresie późniejszym podlegał niewielkim zmianom, dodawano kolejne kategorie w zależności od rodzaju spraw, którymi się zajmowano ${ }^{22}$. Większość oddziałów (Biała Podlaska, Chełm, jak również wspomniane w poprzednim podrozdziale Kraśnik, Lublin miasto, Opole

${ }^{21}$ APL, 720 Związek Bojowników o Wolność i Demokrację Zarząd Wojewódzki w Lublinie, sygn. 165 Protokóły z posiedzeń Prezydium Zarz. Oddziału Miejskiego ZBoWiD w Lublinie, Umowa zlecenie dla Heleny Zielińskiej na prowadzenie sekretariatu z 1 VI 1971, Umowa zlecenie dla Eugenii Owsiak na prowadzenie kartoteki raportów kasowych z 1 VI 1971; sygn. 199 Materiały różne z zakresu organizacji pracy biura byłego Zarządu Okręgu ZBoWiD w Lublinie, Pismo Zarządu Oddziału ZBoWiD w Puławach do Zarządu Okręgu ZBoWiD z 19 I 1968.

${ }^{22}$ APL, 1562 Archiwum Państwowe w Lublinie, sygn. 1027 Związek Bojowników o Wolność i Demokrację Stowarzyszenie Wyższej Użyteczności Zarząd Wojewódzki w Lublinie - protokoły wizytacji, wnioski na brakowanie, Protokół z wizytacji składnicy akt [Zarządu Wojewódzkiego ZBoWiD w Lublinie] przeprowadzonej 19 IX 1956, Protokół wizytacji składnicy akt [Zarządu Wojewódzkiego ZBoWiD w Lublinie] przeprowadzonej 20 XII 1958, Protokół wizytacji archiwum przyzakładowego w Zarządzie Okręgu ZBoWiD w Lublinie przeprowadzonej dnia 22 IX 1965, Protokół wizytacji archiwum przyzakładowego w Zarządzie Okręgu ZBoWiD w Lublinie przeprowadzonej dnia 20 VI 1970, 
Lubelskie, Tomaszów Lubelski i inne) posługiwała się systemem dziennikowym, natomiast system bezdziennikowy był znaczniej mniej popularny ${ }^{23}$. Wynikało to przede wszystkim z woli urzędników stosujących obydwa systemy i subiektywnej oceny przydatności pierwszego bądź drugiego systemu w codziennej pracy kancelaryjnej. W obydwu przypadkach zachowywano znaczą różnorodność w zakresie znakowania i rejestracji pism. W związku z tym przeprowadzone już na początku lat 60. przez przedstawicieli Zarządu Głównego kontrole wykryły w samym Zarządzie Wojewódzkim wiele poważnych błędów i niedociągnięć w zakresie prowadzenia czynności kancelaryjnych. Zarzucono pracownikom m.in. popełnienie licznych błędów przy prowadzeniu dziennika podawczego, w związku z czym nie można było stwierdzić ilości pism wpływających i załatwionych, ponadto brakowało kartoteki akt członkowskich, które z kolei umieszczono w segregatorach z podziałem na oddziały, podczas gdy zgodnie z zaleceniami wizytatorów powinny być umieszczone w teczkach i segregatorach w porządku alfabetycznym. Podobne braki zauważono w Oddziale Miejskim ZBoWiD w Lublinie ${ }^{24}$. Próby ujednolicenia produkcji kancelaryjnej w zasadzie nie odgrywały większej roli i pozostawały często propozycjami na papierze. Na przykład w Kole Dzielnicowym nr 2 w Lublinie na posiedzeniu Zarządu 16 marca 1968 zaproponowano podział korespondencji według grup rzeczowych (teczek spraw): sprawy ogólne oznaczone symbolem K-10/Og/ /68 [w puste miejsce wpisywać miano numer sprawy - przyp. aut.], sprawy organizacyjne (K-10/ Org/ /68), sprawy weryfikacyjno-odznaczeniowe (K-10/WO//68), sprawy socjalno-bytowe (K-10/SB/ /68), sprawy kulturalno-oświatowe (K-10/SK/ /68) $)^{25}$. W zakresie stosowania instrukcji kancelaryjnych i wykazów akt również obowiązywała pewna dowolność z uwagi na opracowanie, wydanie i zalecenie do stosowania jednolitej instrukcji kancelaryjnej, instrukcji o prowadzeniu archiwum zakładowego i jednolitego wykazu akt dopiero 23 lutego 1979. Wcześniej posługiwano się rozwiązaniami doraźnymi, np. w Białej Podlaskiej stosowano instrukcję archiwalną wydaną przez Zarząd Główny jeszcze w 1955 roku (to samo rozwiązanie przyjęto w Zarządzie Wojewódzkim w 1956 roku) oraz wykaz akt typowych, stanowiący załącznik do

Protokół wizytacji archiwum zakładowego [Zarządu Wojewódzkiego] ZBoWiD przeprowadzonej dnia 23 XI 1973.

${ }^{23}$ Tamże, sygn. 1072, Protokół wizytacji składnicy akt [Zarządu Wojewódzkiego ZBoWiD w Białej Podlaskiej] przeprowadzonej 14 V 1982 przez ob. Stefanię Domijańską, Notatka służbowa z pobytu służbowego przedstawiciela WAP w Lublinie mgr F. Pomarańskiej w dniu 7 XI 1975 w Zarządzie Oddziału Powiatowego ZBoWiD w Bychawie, Protokół wizytacji składnicy akt [Zarządu Wojewódzkiego ZBoWiD w Chełmie] przeprowadzonej dnia 13 XII 1982 przez ob. mgr. Stanisława Minickiego, Pismo Wojewódzkiego Archiwum Państwowego do Naczelnej Dyrekcji Archiwów Państwowych z 21 XII 1982.

${ }^{24}$ APL, 720 Związek Bojowników o Wolność i Demokrację Zarząd Wojewódzki w Lublinie, sygn. 173 Protokóły Komisji Odznaczeniowej b. Zarządu Oddziału Miejskiego ZBoWiD, Sprawozdanie z wizytacji Zarządu Okręgu ZBoWiD w Lublinie przeprowadzonej przez płk. Tadeusza Owczarka i Mariana Mirgesa inspektorów Zarządu Głównego ZBoWiD w dniach 8-9 XII 1960.

${ }^{25}$ Tamże, sygn. 156 Protokóty z zebrań Koła Nr 2 ZBoWiD, Protokół nr 2 z posiedzenia Zarządu Koła nr 10 ZBoWiD w Lublinie odbytego w dniu 16 III 1968. 
zarządzenia Ministra Szkolnictwa Wyższego z 9 kwietnia 1963 w sprawie podziału materiałów archiwalnych na kategorie i ustalenia terminów ich przechowywania ${ }^{26}$.

\section{Podstawowe rodzaje dokumentacji i pomocy biurowych}

Wytwarzaną przez komórki ZBoWiD-u podstawową dokumentację pomimo jej różnorodności starano się grupować w jednorodne kategorie w oparciu o nieliczne przepisy i na tej podstawie porządkować pracę kancelarii. Na przykład w Oddziale Miejskim ZBoWiD w Lublinie pod koniec lat 60. wszystkie dokumenty wydzielono według spraw i założono dla nich osobne teczki: personalne (teczka nr 1), finansowe ( $\mathrm{nr}$ 2), socjalno-bytowe (nr 3), weryfikacyjne ( $\mathrm{nr} 4)$, organizacyjno-propagandowe (nr 5), odznaczeniowe (nr 6), protokoły posiedzenia Zarządu (nr 7), sprawy Komisji Rewizyjnej (nr 8), sprawy do załatwienia (nr 9), sprawy radcy prawnego (nr 10), sprawy różne (nr 11), sprawy do rozpatrzenia przez Zarząd (nr 12), skargi i zażalenia (nr 13), plany i sprawozdania (nr 14). Dochodziła do tego prowadzona alfabetycznie ewidencja członków w postaci kartoteki ze skorowidzem, dzielącej w swojej ostatecznej wersji członków Związku pod kątem ich przynależności do konkretnego koła w celu uniknięcia pomyłek, takich jak powtórne wpisanie, zarejestrowanie osoby w dwóch różnych kołach lub niedopatrzenie jej skreślenia na wypadek śmierci, usunięcia z organizacji lub wyjazdu. Prowadzono także ścisłą kontrolę wszelkich druków ścisłego zarachowania (znaczki, legitymacje członkowskie i lecznicze), opłat członkowskich oraz spraw finansowych w postaci ksiąg i kontrolek (np. w Oddziale w Chełmie założono główną i podręczną księgę kasową). W pozostałych oddziałach Związku sytuacja była zbliżona ${ }^{27}$. Znaczna liczba oddziałów (np. Kraśnik, Lublin miasto,

${ }^{26}$ APL, 1562 Archiwum Państwowe w Lublinie, sygn. 1027 Zwiazek Bojowników o Wolność i Demokrację Stowarzyszenie Wyższej Użyteczności Zarząd Wojewódzki w Lublinie - protokoły wizytacji, wnioski na brakowanie, Protokół z wizytacji składnicy akt [Zarządu Wojewódzkiego ZBoWiD w Lublinie] przeprowadzonej 19 IX 1956, Pismo Wojewódzkiego Archiwum Państwowego do Naczelnej Dyrekcji Archiwów Państwowych z 21 XII 1982.

${ }^{27}$ Oddział Puławy posiadał następujące rodzaje spraw, uporządkowanych w oddzielnych segregatorach: sprawy odznaczeniowe, socjalno-bytowe, weryfikacyjno-odznaczeniowe, organizacyjne, Sądu Koleżeńskiego, różne, zarządzenia i okólniki, plany pracy, oczekujące załatwienia, protokoły posiedzeń. Zob.: APL, 720 Związek Bojowników o Wolność i Demokrację Zarząd Wojewódzki w Lublinie, sygn. 103 Protokóly z posiedzeń Prezydium Zarz. Miejskiego ZBoWiD w Lublinie, Protokół z kontroli działalności organizacyjnej i finansowej Oddziału Miejskiego ZBoWiD w Lublinie przeprowadzonej przez Komisję Rewizyjną [za okres 16 I 1963-30 IX 1965]; sygn. 134 Materiały z uroczystości z okazji XXVIII rocznicy napaści na Polskę, Wykaz teczek spraw Oddziału Miejskiego ZBoWiD w Lublinie; sygn. 270 Protokóty z posiedzeń b. Zarządu Oddziału ZBoWiD w Krasnymstawie, Protokół z posiedzenia Zarządu Oddziału ZBoWiD w Krasnymstawie w dniu 10 V 1961; sygn. 275 Protokóły z posiedzeń b. Zarządu Oddziału ZBoWiD w Radzyniu Podlaskim, Protokół z kontroli działalności Zarządu Oddziału Powiatowego ZBoWiD w Radzyniu Podlaskim dokonanej w dniu 4 XII 1965; sygn. 313 Protokóły z posiedzeń Prezydium, plenarnych posiedzeń i sprawozdania z działalności Zarzadu Oddziału Pow. ZBoWiD w Puławach, Protokół nr 24 zdawczo-odbiorczy spisany w dniu 1 X 1974 w sprawie zdania obowiązków i dokumentów biurowych sekretarza technicznego Zarządu Oddziału ZBoWiD w Puławach. 
Opole Lubelskie, Tomaszów Lubelski i inne) stosowały do rejestracji wpływającej korespondencji dzienniki podawcze ${ }^{28}$. Rodzaje posiadanych przez każdą komórkę organizacyjną Związku pieczęci to: stempel firmowy (pieczęć podłużna z dokładną nazwą komórki i danymi adresowymi), pieczęć trójkątna (do pieczętowania różnego rodzaju dokumentów, np. odpisów protokołów i sprawozdań przesłanych do Zarządu Okręgu, tego rodzaju stemple posiadały wyłącznie oddziały), pieczęć wpływu (używana do pieczętowania korespondencji przychodzącej), pieczęć „,pilne” (do pieczętowania korespondencji oczekującej niezwłocznej odpowiedzi, stosowano ją przede wszystkim na potrzeby sprawozdań nadsyłanych przez Zarząd Okręgu lub Zarząd Główny oddziałom, które były zobowiązane odesłać je po wypełnieniu), pieczęć Prezesa Zarządu Oddziału, innych członków Zarządu, mała pieczęć okrągła oraz datownik ${ }^{29}$.

W kołach ZBoWiD-u podstawową dokumentację stanowiły ankiety członkowskie oraz ewidencja tworzona na ich podstawie, zgodnie z rozporządzeniem Zarządu Głównego z 23 września 1961, w formie spisów alfabetycznych lub kartotek. Protokoły posiedzeń zarządów, zebrań sprawozdawczo-wyborczych i zebrań członków kół w miarę możliwości starano się prowadzić w formie książkowej, jednak nie było to rygorystycznie przestrzegane, jako że zwykle ograniczano się do protokołowania na luźnych kartkach. Skompletowane protokoły wraz ze wszystkimi załącznikami (zaproszenia, uchwały, rezolucje, sprawozdania i referaty sprawozdawcze, listy obecności) składano w osobnych teczkach, w pewnych przypadkach do protokołów numerowanych kolejno dołączano sporządzony na podstawie numerów rejestr protokołów (czyniono tak np. w Kole Terenowym w Jastkowie). Podobnie przechowywano akta komisji rewizyjnych i komisji problemowych, instrukcje, wytyczne i zarządzenia przesyłane przez władze naczelne ZBoWiD-u, okręg i macierzyste oddziały. W razie potrzeby zakładano teczki dla korespondencji przychodzącej

${ }^{28}$ Tamże, sygn. 103 Protokóły z posiedzeń Prezydium Zarz. Miejskiego ZBoWiD w Lublinie, Protokół z kontroli działalności organizacyjnej i finansowej Oddziału Miejskiego ZBoWiD w Lublinie przeprowadzonej przez Komisję Rewizyjną [za okres 16 I 1963-30 IX 1965]; sygn. 327 Protokóty z posiedzeń Prezydium, plany pracy $i$ sprawozdania z działalności b. Zarzadu Oddziału Pow. ZBoWiD w Opolu Lub., Protokół z dorywczej kontroli przeprowadzonej w dniu 26 VII 1972 w Zarządzie Oddziału Powiatowego ZBoWiD w Opolu Lubelskim przez Okręgową Komisję Rewizyjną; sygn. 335 Wykazy kół terenowych, protokóly z plenarnych posiedzeń Prezydium, sprawozdania komisji rewizyjnej oraz materiaty VII Zjazdu b. Zarzadu Oddziatu Pow. ZBoWiD w Kraśniku, Sprawozdanie Komisji Rewizyjnej przy Oddziale Powiatowym ZBoWiD w Kraśniku z przeprowadzonej kontroli działalności Zarządu za okres od 1 I 1969 do 31 V 1971; sygn. 341 Protokóły z plenarnych posiedzeń, walnych Zjazdów i sprawozdania z działalności b. Zarzadu oddziału Pow. ZBoWiD w Tomaszowie Lub., Protokół z przeprowadzonej rewizji przez Komisję Rewizyjną czynności Oddziału Powiatowego ZBoWiD w Tomaszowie Lubelskim w dniu 18 II 1961.

${ }^{29}$ Tamże, sygn. 132 Materiaty z V Konferencji Delegatów Zarządu Oddz. Miejskiego ZBoWiD, Sprawozdanie z przebiegu pracy porządkowej kartoteki członków ZBoWiD Oddziału Miejskiego w Lublinie i jej zakończenia 10 I 1971; sygn. 313 Protokóły z posiedzeń Prezydium, plenarnych posiedzeń i sprawozdania z działalności Zarzadu Oddziału Pow. ZBoWiD w Puławach, Protokół nr 24 zdawczo-odbiorczy spisany w dniu 1 X 1974 w sprawie zdania obowiązków i dokumentów biurowych sekretarza technicznego Zarządu Oddziału ZBoWiD w Puławach. 
i wychodzącej (układano je chronologicznie w oddzielnych skoroszytach), spraw do załatwienia oraz już załatwionych. Korespondencję rejestrowano w dziennikach podawczych. Wielokrotnie zdarzało się władzom kół zakładać teczki oznaczone jako „teczki dokumentów różnych”, w których grupowano akta poświęcone wszystkim tym sprawom, które nie mieściły się w obrębie wyżej wymienionych grup rzeczowych. Dokumentację finansową prowadzono w formie raportów kasowych jako rozwiązania najbardziej ekonomicznego i zalecanego do stosowania. W posiadaniu kół znajdowały się również pieczęcie: stempel firmowy (pieczęć podłużna koła z dokładną nazwą i danymi adresowymi), pieczęcie prezesa, sekretarza, skarbnika i przewodniczącego Komisji Rewizyjnej ${ }^{30}$.

${ }^{30}$ Tamże, sygn. 35 Protokóty i sprawozdania z zebrań Kót Terenowych Zarząu Wojewódzkiego ZBoWiD w Lublinie, Protokół z przekazanego majątku Koła Terenowego w Biskupicach zgodnie z decyzją Zarządu Głównego ZBoWiD o rozwiązaniu koła, Pismo Zarządu Oddziału Powiatowego ZBoWiD z 27 VIII 1975, Sprawozdanie z działalności Koła Terenowego ZBoWiD w Jastkowie [na zebranie sprawozdawczo-wyborcze w dniu 9 III 1975]; sygn. 39 Protokóly i sprawozdania z zebrań Kól terenowych Zarzadu Wojewódzkiego ZBoWiD w Lublinie, Pismo Koła Gminnego ZBoWiD w Chodlu do Zarządu Wojewódzkiego ZBoWiD w Lublinie z 5 X 1977; sygn. 85 Protokóty z zebrań Koła Dzielnicowego ZBoWiD nr 11 w Lublinie, Protokół zdawczo-odbiorczy z 1 IV 1965; sygn. 109 Protokóly z zebrań Koła ZBoWiD Nr 13, Protokół nr 3 z posiedzenia Zarządu Koła nr 13 ZBoWiD w Lublinie dnia 3 IX 1970; sygn. 117 Protokóty zebrań Kót ZBoWiD WZGS SCh i FSC, Sprawozdanie Zarządu Koła ZBoWiD przy FSC za okres 1967-1971; sygn. 124 Protokóty z zebrań Koła ZBoWiD nr 2, Sprawozdanie Komisji Rewizyjnej Dzielnicowego Koła nr 2 ZBoWiD w Lublinie na walne zebranie sprawozdawczo-wyborcze w dniu 14 III 1973; sygn. 129 Protokóty z zebrań Koła ZBoWiD Nr 3, Sprawozdanie z kadencji Koła Dzielnicowego nr 3 ZBoWiD w Lublinie za czas od 12 III 1968 do 26 III 1971; sygn. 130 Protokóty z zebrań Koła ZBoWiD przy DOKP w Lublinie, Pismo Zarządu Koła przy DOKP w Lublinie do Zarządu Oddziału Miejskiego ZBoWiD w Lublinie z 20 III 1961, Protokół z dokonanej kontroli przez Komisję Rewizyjną Koła ZBoWiD przy DOKP Lublin w dniu 31 VII 1969 za okres od 1 I do 30 VI 1969; sygn. 131 Protokóty z zebrań Koła ZBoWiD DOKP, Sprawozdanie Komisji Rewizyjnej Koła ZBoWiD przy DOKP z kontroli działalności Zarządu Koła za okres od dnia 24 III 1968 do 14 V 1971; sygn. 156 Protokóły z zebrań Koła Nr 2 ZBoWiD, Protokół nr 2/Plen z posiedzenia plenarnego Zarządu Koła Dzielnicowego nr 2 ZBoWiD w Lublinie odbytego w dniu 4 II 1971, Protokół komisji rewizyjnej z przeprowadzonej kontroli działalności Dzielnicowego Koła nr 10 ZBoWiD w Lublinie spisany w dniu 18 XI 1969, Protokół nr 7/Plen z posiedzenia plenarnego Zarządu Koła Dzielnicowego nr 2 ZBoWiD w Lublinie odbytego w dniu 15 IX 1971; sygn. 199 Materiaty różne z zakresu organizacji pracy biura byłego Zarządu Okręgu ZBoWiD w Lublinie, Pismo Zarządu Głównego ZBoWiD do Zarządu Oddziału ZBoWiD w Łukowie z 21 III 1968; sygn. 272 Protokóły z posiedzeń b. Zarzadu Oddziatu ZBoWiD w Krasnymstawie oraz kwestionariusze członka władz i aktywu ZBoWiD, Plan pracy Zarządu Oddziału Powiatowego ZBoWiD w Krasnymstawie na rok 1966; sygn. 277 Protokóty z posiedzeń b. Zarzadu Oddziału ZBoWiD w Krasnymstawie oraz kwestionariusze członka władz i aktywu ZBoWiD, Sprawozdanie Komisji Rewizyjnej Terenowego Koła ZBoWiD w Kraśniczynie za okres od 24 I 1971 do 11 III 1973; sygn. 284 Protokóły z Walnych Zjazdów i posiedzeń Prezydium b. Zarzadu Oddziatu Pow. ZBoWiD w Chetmie, Protokół Komisji Rewizyjnej z przeprowadzonej kontroli działalności administracyjnej i księgowo-finansowej w Zarządzie Oddziału Powiatowego ZBoWiD w Chełmie dnia 23 VII 1963 r.; sygn. 287 Protokóty z plenarnych posiedzeń i sprawozdania z działalności b. Zarzadu Oddziału Pow. ZBoWiD w Chetmie oraz kwestionariusze członka władz i aktywu ZBoWiD, Sprawozdanie z działalności Komisji Rewizyjnej Zarządu ZBoWiD w Chełmie [z 1968 roku]; sygn. 291 Protokóty z posiedzeń Zjazdu organizacyjnego i plenarnych posiedzeń b. Zarzadu Oddziału Pow. ZBoWiD w Zamościu, Protokół z przeprowadzonej w dniu 29 V 1957 kontroli działalności finansowej Zarządu Powiatowego ZBoWiD w Zamościu; sygn. 353 Protokóty z posiedzeń Prezydium, narady z prezesami kół i działalności b. Zarządu Oddziału Miejskiego ZBoWiD w Lublinie, Protokół Komisji Rewizyjnej 


\section{Postępowanie z dokumentacją i obieg pism}

Kancelaria ZBoWiD-u odpowiadała organizacyjnie typowi kancelarii zdecentralizowanej. Dokumentacja potrzebna do bieżącego funkcjonowania znajdowała się w posiadaniu odpowiedzialnych za nią urzędników w pomieszczeniach biurowych Związ$\mathrm{ku}^{31}$, natomiast materiały $\mathrm{z}$ lat ubiegłych składano początkowo również $\mathrm{w}$ tychże pomieszczeniach, następnie zaś we własnej składnicy akt. Przekazywanie dokumentacji przez zmieniających się na swoich stanowiskach sekretarzy technicznych było uregulowane koniecznością sporządzenia protokołu zdawczo-odbiorczego, w którym ustępujący wymieniał ilość i rodzaj materiałów powierzanych swojemu następcy ${ }^{32}$. Korespondencję przychodzącą otrzymywał w pierwszym rzędzie sekretarz komórki, czyli kierownik biura, który przeglądał korespondencję, odciskał na niej w prawnym górnym lub lewym dolnym rogu pieczęć wpływu składającą się z: nazwy jednostki macierzystej, znaku pisma nadawanego wpływającej korespondencji oraz daty wpływu pisma. W komórkach stosujących system dziennikowy pisma wpisywano do dzienników podawczych zawierających następujące rubryki: „1.p.”, „data wpły-

ZBoWiD przy Kole nr 12 LSM w Lublinie z działalności Koła za okres od 1 I do 30 XII 1972 sporządzony w dniach 30 XII 1972 i 3 I 1973.

${ }^{31}$ Brak miejsca, lokalu, często również zbyt wygórowane ambicje kierownicze niektórych prezesów, zwłaszcza w kołach terenowych, powodowały, że prace biurowe wykonywano i dokumentację przechowywano w prywatnych mieszkaniach. Taka sytuacja panowała m.in. w Kole Dzielnicowym nr III „3 Maja” za prezesury Haliny Łukawskiej, w Kole Dzielnicowym nr X „Dziesiąta” w Lublinie, w Kole Dzielnicowym nr XIII „Wieniawa”. Zob.: tamże, sygn. 109 Protokóty z zebrań Koła ZBoWiD $\mathrm{Nr}$ 13, Protokół z zebrania sprawozdawczo-wyborczego Dzielnicowego Koła nr 13 ZBoWiD w Lublinie odbytego w dniu 17 I 1971; sygn. 118 Protokóty z zebrań Kót dzielnicowych ZBoWiD Nr 1 i 10 w Lublinie, Sprawozdanie z działalności Dzielnicowego Koła nr 10 ZBoWiD w Lublinie działającego w dzielnicy Dziesiąta za okres od 24 II 1973 do 16 V 1974; sygn. 128 Protokóty z zebrań Koła ZBoWiD Nr 4, Pismo Zarządu Koła Dzielnicowego ZBoWiD nr 3 do Zarządu Oddziału Miejskiego ZBoWiD w Lublinie z 17 I 1972, Protokół nr 8 z nadzwyczajnego zebrania Zarządu Koła nr 3 ZBoWiD w Lublinie z 17 IV 1973, Pismo Zarządu Koła Dzielnicowego ZBoWiD nr 3 do Zarządu Oddziału Miejskiego ZBoWiD w Lublinie z V 1973, Sprawozdanie informacyjne z działalności Zarządu Koła Dzielnicowego nr 3 ZBoWiD w Lublinie za okres od 20 XII 1972 do 30 IX 1973; sygn. 148 Protokóty z posiedzeń Prezydium b. Zarz. Oddziału Miejskiego ZBoWiD w Lublinie, Protokół nr 11 z odbytego posiedzenia Prezydium Zarządu Oddziału Miejskiego ZBoWiD w Lublinie z dnia 21 II 1968.

${ }^{32}$ Tamże, sygn. 112 Protokóły z zebrań Koła ZBoWiD Nr 5, Protokół zdawczo-odbiorczy przekazania dokumentów Koła nr 5 ZBoWiD w Lublinie [na podstawie zebrania sprawozdawczo-wyborczego z dnia 28 III 1965]; sygn. 313 Protokóty z posiedzeń Prezydium, plenarnych posiedzeń i sprawozdania z działalności Zarzadu Oddziału Pow. ZBoWiD w Puławach, Protokół nr 24 zdawczo-odbiorczy spisany w dniu 1 X 1974 w sprawie zdania obowiązków i dokumentów biurowych sekretarza technicznego Zarządu Oddziału ZBoWiD w Puławach; sygn. 341 Protokóty z plenarnych posiedzeń, walnych Zjazdów i sprawozdania z działalności b. Zarządu oddziału Pow. ZBoWiD w Tomaszowie Lub., Protokół zdawczo-odbiorczy akt i sprzętów biurowych kancelarii sekretariatu Zarządu Oddziału ZBoWiD w Tomaszowie Lubelskim dokonanego przekazania kancelarii sekretarzowi technicznemu Mościbrodzie Feliksowi w dniu 6 VII 1960; sygn. 355 Plany pracy, protokóły z posiedzeń Prezydium oraz kwestionariusze członka władz i aktywu ZBoWiD b. Zarządu Oddziału Pow. w Lublinie, Protokół zdawczo-odbiorczy spisany w dniu 3 VIII 1963 w sprawie przejęcia akt ZBoWiD Zarząd Powiatowy w Lublinie przy obecności przedstawiciela ZBoWiD Zarząd Okręgu ob. Zapiórkowskiego Władysława. 
wu”, „od kogo korespondencja wpłynęła”, „data i liczba instytucji lub osoby, która nadesłała korespondencję", ,treść otrzymanej korespondencji” (lewa strona dziennika), „komu korespondencję przydzielono do załatwienia”, „do kogo korespondencję odesłano”, „data wysłania załatwionej korespondencji”, „treść załatwionej korespondencji”, ,u kogo akta danej korespondencji przechowują się”, ,uwagi”33. Z rejestracji wyłączone były instrukcje i zarządzenia władz naczelnych Związku, druki ulotne, broszury, gazety. Opieczętowane akta kierownik biura przekazywał z kolei urzędującemu wiceprezesowi, który odręcznie dekretował pisma, uzupełniając niewypełnioną rubrykę pieczęci wpływu „skierowano do”, względnie w lewym górnym rogu pisma czynił na marginesie odręczne notatki dotyczące szczegółów załatwienia sprawy. Tak przygotowana korespondencja trafiała do właściwych referentów ${ }^{34}$. Korespondencja wychodząca na wszystkich szczeblach organizacyjnych Związku musiała być zaopiniowana przez Zarząd (referent prowadzący sprawę sporządzał brudnopis odpowiedzi, przedstawiał go swojemu przełożonemu, który nanosił poprawki, następnie po naniesieniu poprawek przez referenta i sporządzeniu czystopisu dokument trafiał ponownie do przełożonego), złożona w odpowiedniej teczce i przedstawiona do podpisu. Pisma opatrywano dwoma podpisami członków Zarządu (prezesa i wiceprezesa, zaś w przypadku nieobecności któregoś z nich podpisem innej upoważnionej osoby, którą zwykle był sekretarz), a w sprawach finansowych - także podpisem skarbnika. Specjalna procedura obowiązywała w przypadku przesyłania korespondencji pomiędzy opiekunem danego oddziału ZBoWiD-u a samym oddziałem w sprawach wymagających jego interwencji. Tego typu pisma Zarząd Oddziału kierował pod adresem Zarządu Wojewódzkiego, dopisując na kopercie „do wiadomości opiekuna”, ów zaś miał obowiązek podawać do wiadomości Zarządu treść odpowiedzi ${ }^{35}$.

\section{Przechowywanie, porządkowanie i przekazywanie akt do archiwum państwowego}

Dokumentację zbędną w bieżącej pracy kancelaryjnej składano w wydzielonym pomieszczeniu - archiwum zakładowym lub składnicy akt. W przypadku trudnych warunków lokalowych akta starsze nadal przechowywano w zamkniętych szafach

33 Tamże, sygn. 32 Protokóty z posiedzeń Zarządu Koła $w$ Zemborzycach protokoty zebrań oraz inna dokumentacja dot. spraw organizacyjnych, Dziennik korespondencyjny [Koła ZBoWiD w Zemborzycach].

${ }^{34}$ Tamże, sygn. 221 Protokóty z posiedzeń Prezydium Zarządu Okręgu ZBoWiD w Lublinie, Protokół nr 16 z posiedzenia Prezydium Zarządu Okręgu ZBoWiD w Lublinie odbytego w dniu 10 I 1964.

${ }^{35}$ Tamże, sygn. 153 Protokóły z posiedzeń Prezydium Zarz. Oddz. Miejskiego ZBoWiD w Lublinie, Protokół nr 3/69 z posiedzenia Zarządu Oddziału Miejskiego ZBoWiD w Lublinie odbytego w dniu 18 II 1969; sygn. 154 Protokóły z posiedzeń Prezydium Zarz. Oddz. Miejskiego ZBoWiD w Lublinie, Protokół nr 3/69 z posiedzenia zarządu Oddziału Miejskiego ZBoWiD w Lublinie odbytego w dniu 18 II 1969; sygn. 275 Protokóły z posiedzeń b. Zarzadu Oddziału ZBoWiD w Radzyniu Podlaskim, Sprawozdanie z pobytu w Zarządzie Powiatowym ZBoWiD w Radzyniu Podlaskim w dniu 21 XI 1962 sporządzone przez opiekuna Stefana Zbyszewskiego. 
w pomieszczeniach biurowych, oddzielnie od dokumentacji stale wykorzystywanej. Szczególną wagę przywiązywano do „dokumentacji historycznej”, stanowiącej głównie produkt działalności komisji historycznych, której wartość podkreślało jej wykorzystywanie i udostępnianie do celów naukowo-badawczych działającym w ramach Związku lub poza nim historykom, regionalistom, przedstawicielom środków masowego przekazu. $Z$ racji braków kadrowych proces uporządkowania tego zasobu odbywał się przy pomocy pracowników-aktywistów działających społecznie lub doraźnie angażowanych sił roboczych ${ }^{36}$.

Proces powstawania archiwów zakładowych Zarządu Wojewódzkiego i jego oddziałów był długotrwały $z$ uwagi na brak odpowiednich pomieszczeń. Pierwsza wizytacja składnicy akt 22 października 1951 stwierdziła przechowywanie akt na strychu w skrzyniach drewnianych lub owiniętych w papier, prace porządkowe będące dopiero w toku oraz brak instrukcji o prowadzeniu składnic akt. Do połowy lat 60 . Okręg nie posiadał swojego archiwum, podobna sytuacja panowała w komórkach terenowych. Do momentu rozpoczęcia prac przygotowawczych związanych z przejęciem akt przez Wojewódzkie Archiwum Państwowe w Lublinie (dalej: WAPL) w archiwach zakładowych i składnicach akt ZBoWiD-u nie prowadzono brakowania i podziału akt na kategorie archiwalne „A” i „B”. Procedura taka była jednak zastosowana jednorazowo przed reaktywowaniem ZBoWiD-u w 1956 roku, kiedy to zarządzeniem władz naczelnych Związku Zarząd Wojewódzki miał być zlikwidowany, zaś akta przekazane do Warszawy. Świadczyły o tym zachowane dokumenty ${ }^{37}$.

W zakresie przechowywanej $\mathrm{w}$ archiwum zakładowym dokumentacji osobowej (akta członkowskie) od 1972 roku na mocy odgórnych zaleceń Zarządu Okręgu uchwalonych na posiedzeniu Prezydium 7 czerwca 1972 zdecydowano się na system teczkowy. Zakładał on znaczne uporządkowanie korespondencji, ankiet, podań i pism dotyczących pojedynczej osoby przez założenie dla niej jednolitej teczki, w której gromadzić miano całą wymienioną dokumentację. Zgodzono się również na zszycie akt i ponumerowanie teczek oraz załączenie do nich spisów spraw. Dodatkową pomocą ewidencyjną miały być księgi zaopatrzone w skorowidze alfabetyczne. Przed zlikwidowaniem oddziałów w 1975 roku teczek tych było ok. 30 tys., zaś w 1977 roku ok. 16 tys. ${ }^{38}$

${ }^{36}$ Tamże, sygn. 46 Protokóły z posiedzeń Prezydium Zarządu Okręgu ZBoWiD w Lublinie, Protokół nr 2/72 z posiedzenia Prezydium Zarządu Okręgu ZBoWiD w Lublinie odbytego w dniu 7 VI 1972.

${ }^{37}$ Tamże, sygn. 173 Protokóły Komisji Odznaczeniowej b. Zarządu Oddziału Miejskiego ZBoWiD, Sprawozdanie z wizytacji Zarządu Okręgu ZBoWiD w Lublinie przeprowadzonej przez płk. Tadeusza Owczarka i Mariana Mirgesa inspektorów Zarządu Głównego ZBoWiD w dniach 8-9 XII 1960; APL, 1562 Archiwum Państwowe w Lublinie, sygn. 1027 Związek Bojowników o Wolność i Demokrację Stowarzyszenie Wyższej Użyteczności Zarząd Wojewódzki w Lublinie - protokoły wizytacji, wnioski na brakowanie, Protokół z wizytacji składnicy akt ZBoWiD Zarządu Okręgowego w Lublinie [z 22 X 1951], Protokół z wizytacji składnicy akt [Zarządu Wojewódzkiego ZBoWiD w Lublinie] przeprowadzonej 19 IX 1956, Protokół wizytacji archiwum przyzakładowego w Zarządzie Okręgu ZBoWiD w Lublinie przeprowadzonej dnia 22 IX 1965.

${ }^{38}$ APL, 1562 Archiwum Państwowe w Lublinie, sygn. 1027 Zwiazek Bojowników o Wolność i Demokrację Stowarzyszenie Wyższej Użyteczności Zarząd Wojewódzki w Lublinie - protokoły wizytacji, 
Odrębnym zagadnieniem były materiały Okręgowej Komisji Historycznej, o których znaczeniu wspomniano wyżej. W 1971 roku jej zasób zawierał ok. 8 m.b. akt posegregowanych na: materiały z działalności organizacyjnej i bojowej członków organizacji konspiracyjnych i oddziałów partyzanckich (uporządkowane w pojedyncze jednostki w zależności od tematyki materiałów) ${ }^{39}$, kartotekę miejsc akcji bojowych, walk i straceń, zbrodni okupanta, członków ruchu oporu oraz relacje. Zaprowadzono stale uaktualniane wykazy relacji. W zasobie znajdowało się również ok. 2000 fotografii (wykonanych przez członków Związku, zebranych w ramach działalności Komisji oraz nadsyłanych na zamówienie odbitek ze zbiorów Centralnej Agencji Fotograficznej), segregowanych według kryterium rzeczowego: poświęcone martyrologii, walce z okupantem, tajnym organizacjom, uroczystościom odsłonięcia pomników oraz zbieranym do kroniki działalności Związku. Fotografie numerowano i ujmowano w specjalnej kartotece. Zbiory te, jak również biblioteka, znajdowały się pod stałym nadzorem pracowników Komisji Historycznej ${ }^{40}$. Zasób ten porządkowano od lat 60., posługując się zarządzeniem nr 16 Naczelnego Dyrektora Archiwów Państwowych z 31 lipca 1960 w sprawie nadzoru archiwów nad składnicami akt oraz w związku z faktem wciągnięcia archiwów komisji historycznych ZBoWiD-u na państwową listę archiwalną ${ }^{41}$. Równocześnie toczyła się również na

wnioski na brakowanie, Protokół wizytacji archiwum zakładowego [Zarządu Wojewódzkiego] ZBoWiD przeprowadzonej dnia 23 XI 1973, Protokół wizytacji składnicy akt [Zarząu Wojewódzkiego ZBoWiD w Lublinie] przeprowadzonej dnia 16 XI 1977, Protokół wizytacji składnicy akt [Zarządu Wojewódzkiego ZBoWiD w Lublinie] przeprowadzonej dnia 3 VIII 1979.

${ }^{39} \mathrm{~W} 1963$ roku teczka poświęcona Armii Ludowej zawierała 41 pozycji, Armii Krajowej 44, Batalionom Chłopskim 22, partyzantce radzieckiej 4, Narodowym Siłom Zbrojnych i zbrodniom reakcji 13, zbrodniom okupanta 18, walkom w 1939 roku 7, działalności rewolucyjnej 14. Były to wyciągi z życiorysów i akt personalnych, odpisy i oryginały dokumentów, zestawienia danych o obsadzie personalnej i krótsze relacje. Zob.: APL, 720 Związek Bojowników o Wolność i Demokrację Zarząd Wojewódzki w Lublinie, sygn. 257 Sprawozdania i materiały z działalności Komisji historyczno-propagandowej za 1963 r., Sprawozdanie z działalności Komisji Historycznej Zarządu Okręgu ZBoWiD w Lublinie za rok 1962 [z 2 I 1963]; sygn. 261 Plany pracy i inne materiaty w zakresie uporzadkowanie miejsc walk $i$ stracen w okresie II wojny światowej, Protokół z posiedzenia Okręgowej Komisji Historycznej w dniu 6 IX 1965.

${ }^{40}$ APL, 720 Związek Bojowników o Wolność i Demokrację Zarząd Wojewódzki w Lublinie, sygn. 19 Obchody 30 rocznicy zwycięstwa nad faszyzmem. Plany pracy Komisji Historycznej, k. 78-88, Pismo Wojewódzkiego Archiwum Państwowego w Lublinie do Naczelnej Dyrekcji Archiwów Państwowych z 28 X 1971; sygn. 28 Protokóły, informacje, uchwaty Prezydium Zarządu Okręgu ZBoWiD w Lublinie, Protokół nr 8 z posiedzenia Prezydium Zarządu Okręgu ZBoWiD w Lublinie odbytego w dniu 7 VII 1965; sygn. 257 Sprawozdania i materiały z działalności Komisji historyczno-propagandowej za 1963 r., Sprawozdanie z działalności Komisji Historycznej Zarządu Okręgu ZBoWiD w Lublinie za rok 1962 [z 2 I 1963], Pismo Zarządu Głównego ZBoWiD do Zarządu Okręgu ZBoWiD z 2 V 1963, Protokół wizytacji składnicy akt w dniu 28 V 1963; 1562 Archiwum Państwowe w Lublinie, sygn. 1027 Zwiazek Bojowników o Wolność i Demokrację Stowarzyszenie Wyższej Użyteczności Zarząd Wojewódzki w Lublinie - protokoły wizytacji, wnioski na brakowanie, Protokół wizytacji składnicy akt [Zarządu Wojewódzkiego ZBoWiD w Lublinie] z 27 X 1961, Protokół z wizytacji składnicy akt [Zarządu Wojewódzkiego ZBoWiD w Lublinie] przeprowadzonej 28 V 1963, Pismo Wojewódzkiego Archiwum Państwowego w Lublinie do Naczelnej Dyrekcji Archiwów Państwowych z 4 VII 1963, Protokół wizytacji archiwum przyzakładowego w Zarządzie Okręgu ZBoWiD w Lublinie przeprowadzonej dnia 22 IX 1965. Zob. też: Aneks 1, dokument nr 10.

${ }^{41}$ APL, 1562 Archiwum Państwowe w Lublinie, sygn. 1027 Związek Bojowników o Wolność i Demokrację Stowarzyszenie Wyższej Użyteczności Zarząd Wojewódzki w Lublinie - protokoły wizytacji, 
łamach prasy związkowej szeroko zakrojona dyskusja nad rzeczywistym znaczeniem tych materiałów oraz propozycjami wysuwanymi przez archiwa państwowe w sprawie ich uporządkowania i przejęcia ${ }^{42}$.

Nadzór WAPL nad Zarządem Wojewódzkim ZBoWiD w Lublinie i podporządkowanymi mu komórkami trwał od lat 50. aż do 1983 roku, kiedy to wszystkie związki posiadające charakter „stowarzyszenia wyższej użyteczności” znalazły się poza nadzorem państwowej służby archiwalnej ${ }^{43}$. Pierwszej wizytacji w składnicy akt (od 22 września 1965 używano określenia „,archiwum przyzakładowe”, od 23 listopada 1973 ,,archiwum zakładowe”, od 16 listopada 1977 ponownie „składnica akt”, w kwietniu 1983 ponownie ,archiwum zakładowe”) Zarządu Wojewódzkiego ZBoWiD dokonano 22 października 1951, ostatniej w dniach 11 i 25 kwietnia $1983^{44}$. Niezależnie od kontroli organizacji wojewódzkiej nadzór archiwalny obejmował także instancje mu podległe, $\mathrm{z}$ których materiały zachowały się jednak dopiero od 1975 roku, w związku z wprowadzeniem w życie uchwały o dwustopniowym podziale administracyjnym państwa i zmianie ustawy o radach narodowych z 28 maja $1975^{45}$, powołaniem trzech nowych zarządów wojewódzkich ZBoWiD-u: w Białej Podlaskiej, Chełmie i Zamościu oraz wynikającą z reformy koniecznością

wnioski na brakowanie, Notatka służbowa z pobytu dnia 17 XII 1970 w Zarządzie Okręgu ZBoWiD, Pismo Wojewódzkiego Archiwum Państwowego w Lublinie do Naczelnej Dyrekcji Archiwów Państwowych z VIII 1970, Notatka służbowa z pobytu dr Marii Stankowej dnia 27 X 1971 w Zarządzie Okręgu ZBoWiD w Lublinie, Notatka służbowa z pobytu dr Marii Stankowej dnia 18 XII 1972 w Zarządzie Okręgu ZBoWiD w Lublinie, Protokół wizytacji archiwum zakładowego [Zarządu Wojewódzkiego] ZBoWiD przeprowadzonej dnia 23 XI 1973, Protokół lustracji archiwum zakładowego Zarządu Wojewódzkiego ZBoWiD w Lublinie przeprowadzonej w dniach 11 i 25 IV 1983. Zob. też: Zbiór przepisów archiwalnych wydanych przez Naczelnego Dyrektora Archiwów Państwowych w latach 1952-2000, s. 79-80.

${ }_{42}$ Archiwalia kombatanckie. Zatrzymać w ZBoWiD czy przekazać do archiwów państwowych? Rozmowa z naczelnym dyrektorem prof. dr. hab. Tadeuszem Walichnowskim, „Za Wolność i Lud”, 21 (1978).

${ }^{43}$ Dz. U. PRL 1983 Nr 38, poz. 173.

${ }^{44}$ Wizytacje prowadzili pracownicy WAPL: asystent Marian Wojtas, dr Maria Stankowa, mgr Stanisława Paulowa, mgr Joanna Nagrodkiewicz, mgr (obecnie dr hab.) Janusz Łosowski, mgr Stefan Janicki. Zob.: APL, 1562 Archiwum Państwowe w Lublinie, sygn. 1027 Zwiazek Bojowników o Wolność i Demokrację Stowarzyszenie Wyższej Użyteczności Zarząd Wojewódzki w Lublinie - protokoty wizytacji, wnioski na brakowanie, Protokół z wizytacji składnicy akt ZBoWiD Zarządu Okręgowego w Lublinie z 22 X 1951, Protokół z wizytacji składnicy akt [Zarządu Wojewódzkiego ZBoWiD w Lublinie] przeprowadzonej 19 IX 1956, Protokół wizytacji składnicy akt [Zarządu Wojewódzkiego ZBoWiD w Lublinie] przeprowadzonej 20 XII 1958, Protokół wizytacji składnicy akt [Zarządu Wojewódzkiego ZBoWiD w Lublinie] przeprowadzonej 27 X 1961, Protokół z wizytacji składnicy akt [Zarządu Wojewódzkiego ZBoWiD w Lublinie] przeprowadzonej 28 V 1963, Protokół wizytacji archiwum przyzakładowego w Zarządzie Okręgu ZBoWiD w Lublinie przeprowadzonej dnia 22 IX 1965, Protokół wizytacji archiwum przyzakładowego w Zarządzie Okręgu ZBoWiD w Lublinie przeprowadzonej dnia 20 VI 1970, Protokół wizy tacji archiwum zakładowego ZBoWiD przeprowadzonej dnia 23 XI 1973, Protokół wizytacji składnicy akt [Zarządu Wojewódzkiego ZBoWiD w Lublinie] przeprowadzonej dnia 16 XI 1977, Protokół wizytacji składnicy akt [Zarządu Wojewódzkiego ZBoWiD w Lublinie] przeprowadzonej dnia 3 VIII 1979, Protokół wizytacji składnicy akt [Zarządu Wojewódzkiego ZBoWiD w Lublinie] przeprowadzonej dnia 24 XI 1982, Protokół lustracji archiwum zakładowego Zarządu Wojewódzkiego ZBoWiD w Lublinie przeprowadzonej w dniach 11 i 25 IV 1983.

${ }^{45}$ Dz. U. PRL $1975 \mathrm{Nr}$ 16, poz. 91. 
likwidacji oddziałów powiatowych ZBoWiD-u i przejęcia wytworzonego przez nie zasobu aktowego przez Zarząd Wojewódzki ZBoWiD w Lublinie ${ }^{46}$.

Procedurę przejęcia materiałów przez WAPL poprzedziły wizytacje, zalecenia i korespondencja, dotyczące opisania i uporządkowania akt zgodnie z art. 4 dekretu o archiwach państwowych z 29 marca 1951 oraz rozporządzeniem Rady Ministrów z 19 lutego 1957 w sprawie państwowego zasobu archiwalnego ${ }^{47}$. Na podstawie pkt 7, ust. 2 i 3 instrukcji o organizacji i zakresie działania archiwów zakładowych dokonano przejęcia materiałów statutowych ZBoWiD-u (szacowanych podczas wizytacji na ok. 4,5 m.b. ${ }^{48}$ w jednostkach organizacyjnych ZBoWiD-u w trzech etapach: w 1980 (przekazano wówczas 197 j.a. o ogólnym metrażu 2,20 m.b.), w 1982 (110 j.a., 1,60 m.b.) i w 1988 (73 j.a., 1,30 m.b.).

W związku z tym w zasobie archiwum znalazło się 380 j.a. o ogólnym metrażu 5,20 m.b. ${ }^{49}$ Przejęte materiały zostały wpisane do księgi nabytków WAPL pod kolejnymi numerami 1937, 1938 i 2326. Utworzono z nich zespół nr 720 ,Związek Bojowników o Wolność i Demokrację Zarząd Wojewódzki w Lublinie 1949-1979”. Podstawowy środek ewidencyjny tego zespołu służący udostępnianiu i opracowaniu

${ }^{46}$ Kontrole w oddziałach powiatowych ZBoWiD prowadzili: Stefania Domijańska (Zarząd Wojewódzki ZBoWiD w Białej Podlaskiej, który w wyniku reformy przejął, a następnie przekazał do Zarządu Wojewódzkiego ZBoWiD w Lublinie akta zlikwidowanych oddziałów powiatowych m.in. w Białej Podlaskiej, Parczewie i Radzyniu Podlaskim), mgr F. Pomarańska (Zarząd Oddziału ZBoWiD w Bychawie), mgr Stanisław Minicki, obecnie dyrektor Archiwum Państwowego w Lublinie Oddział w Chełmie (Zarząd Wojewódzki ZBoWiD w Chełmie, który w wyniku reformy przejął, a następnie przekazał do Zarządu Wojewódzkiego ZBoWiD w Lublinie m.in. akta zlikwidowanego Zarządu Oddziału ZBoWiD w Chełmie), mgr Zbigniew Gąszczyk (Zarząd Oddziału ZBoWiD w Puławach), dr Franciszek Cieślak (Klub byłych Więźniów Politycznych Zamku Lubelskiego i „Pod zegarem” w Lublinie). Dokumentów potwierdzających przeprowadzenie kontroli w innych oddziałach ZBoWiD nie odnaleziono. Zob.: APL, 1562 Archiwum Państwowe w Lublinie, sygn. 1027 Związek Bojowników o Wolność i Demokrację Stowarzyszenie Wyższej Użyteczności Zarząd Wojewódzki w Lublinie - protokoły wizytacji, wnioski na brakowanie, Protokół wizytacji składnicy akt [Zarządu Wojewódzkiego ZBoWiD w Białej Podlaskiej] przeprowadzonej 14 V 1982, Notatka służbowa z pobytu służbowego przedstawiciela WAP w Lublinie mgr F. Pomarańskiej w dniu 7 XI 1975 w Zarządzie Oddziału Powiatowego ZBoWiD w Bychawie, Protokół wizytacji składnicy akt [Zarządu Wojewódzkiego ZBoWiD w Chełmie] przeprowadzonej dnia 13 XII 1982, Protokół z wizytacji archiwum zakładowego [Zarządu Oddziału Powiatowego ZBoWiD w Puławach] przeprowadzonej dnia 3 X 1975, Protokół wizytacji archiwum zakładowego [Klubu byłych Więźniów Politycznych Zamku Lubelskiego i „Pod zegarem” w Lublinie] przeprowadzonej dnia 22 VI 1982.

${ }^{47}$ Dz. U. PRL 1951 Nr 19, poz. 149; 1957 Nr 12, poz. 66; 1959 Nr 2, poz. 12. Zob. też: APL, 1562 Archiwum Państwowe w Lublinie, sygn. 1027 Związek Bojowników o Wolność i Demokrację Stowarzyszenie Wyższej Użyteczności Zarząd Wojewódzki w Lublinie-protokoly wizytacji, wnioski na brakowanie, Pismo Wojewódzkiego Archiwum Państwowego w Lublinie do prezesa Zarządu Wojewódzkiego ZBoWiD w Lublinie z 10 VIII 1979.

${ }^{48}$ APL, 1562 Archiwum Państwowe w Lublinie, sygn. 1027 Związek Bojowników o Wolność i Demokrację Stowarzyszenie Wyższej Użyteczności Zarząd Wojewódzki w Lublinie - protokoły wizytacji, wnioski na brakowanie, Pismo Wojewódzkiego Archiwum Państwowego w Lublinie do Naczelnej Dyrekcji Archiwów Państwowych z XI 1982.

${ }^{49}$ APL, 720 Związek Bojowników o Wolność i Demokrację Zarząd Wojewódzki w Lublinie (teczka zespołu), Pismo Zarządu Wojewódzkiego ZBoWiD do Wojewódzkiego Archiwum Państwowego w Lublinie z 12 V 1980, Pismo Zarządu Wojewódzkiego ZBoWiD do Wojewódzkiego Archiwum Państwowego w Lublinie z 26 III 1982, Pismo Zarządu Wojewódzkiego ZBoWiD do Wojewódzkiego Archiwum Państwowego w Lublinie z 3 VII 1988. 
stanowią w chwili obecnej trzy spisy zdawczo-odbiorcze ${ }^{50}$, które dla łatwiejszego korzystania z nich w celach badawczych i przeprowadzania kwerend połączono, nadając jednostkom sygnatury ciągłe. W wyniku przejęcia, do WAPL trafiły materiały określone wyłącznie jako kategoria „A”. Obejmują one dokumenty wytworzone przez Zarząd Okręgu i Zarząd Wojewódzki ZBoWiD w Lublinie w latach 1949-1979 oraz oddziały powiatowe w latach 1949-1975. Dokumentacja wytworzona w latach 1980-1990 pozostała $\mathrm{w}$ archiwum zakładowym ZBoWiD-u i została przejęta $\mathrm{w}$ formie sukcesji przez lokalne struktury Związku Kombatantów Rzeczypospolitej Polskiej i Byłych Więźniów Politycznych ${ }^{51}$.

Instrukcja $\mathrm{w}$ sprawie segregowania akt związkowych dla centralnego archiwum Związku Bojowników o Wolność i Demokrację oraz dla przekazania na makulaturę [z lipca 1954 roku] ${ }^{52}$

Zarząd Główny Warszawa, lipiec 1954 roku Związku Bojowników o Wolność i Demokrację w Warszawie

a(wpływ 20.VII.1954 r. znak: 241/Org/54)a

\section{Podział akt na kategore A i B}

1. Wszelkie akta spraw zakończonych, niepotrzebne do pracy bieżącej biura Zarządu Okręgu, Oddziału należy podzielić na akta mające znaczenie trwałe: kategorii A i na akta mające znaczenie czasowe: kategorii $\mathrm{B}$.

${ }^{50}$ Tamże, Spis akt kat. „A” przekazanych ze składnicy akt z 12 V 1980, Spis akt kat. „A” przekazanych ze składnicy akt z 23 III 1982, Spis akt kat. „A” przekazanych ze składnicy akt z 18 VII 1988.

${ }^{51}$ W latach 1979-1981 we współpracy z WAPL (w postaci ekspertyz, zaleceń i decyzji wydawanych przez Komisję Oceny Dokumentacji Archiwalnej WAPL) dokonano brakowania akt Zarządu Wojewódzkiego ZBoWiD w Lublinie celem przygotowania ich do przekazania do WAPL, wyłączenia akt kat. „A” i zniszczenia akt kat. „B”. Na podstawie przedkładanych przez przedstawicieli ZBoWiD spisów akt kat. „B” zezwolono na wybrakowanie akt kat. „B” (złożyły się na nią kopie pism i wniosków w sprawach rentowych, przyznania zapomóg, miejsc w sanatoriach, odszkodowań, odznaczeniowych, weryfikacyjnych, podania o wydanie duplikatów legitymacji członkowskich i leczniczych, dzienniki korespondencyjne z lat 1956-1960 i 1974-1975), polecając wyłączenie z nich części akt błędnie zakwalifikowanych jako kat. „B” (głównie dokumentacja w sprawach organizacyjnych). Zob.: APL, 1562 Archiwum Państwowe w Lublinie, sygn. 1027 Zwiąek Bojowników o Wolność i Demokracje Stowarzyszenie Wyższej Użyteczności Zarząd Wojewódzki w Lublinie - protokoły wizytacji, wnioski na brakowanie, Protokół brakowania akt z 7 XII 1979, Protokół brakowania akt z 21 XII 1979, Protokół brakowania akt z 29 I 1980; Protokół brakowania akt z 27 II 1981, Protokół Komisji Archiwalnej Oceny Dokumentacji z 18 I 1980; Protokół Komisji Archiwalnej Oceny Dokumentacji z 6 II 1980.

52 APL, 720 Związek Bojowników o Wolność i Demokrację Zarząd Wojewódzki w Lublinie, sygn. 234 Protokóły z posiedzeń Zarządu Okręgu ZBoWiD, uchwaty, sprawozdania, korespondencja. Wspomnianą instrukcję zamieszczono jako jeden z najwcześniejszych dokumentów dotyczących przekazywania akt struktur terenowych ZBoWiD do jednostki wyższego rzędu oraz podziału ich na kat. „A” i „B”.

a-a Pieczęć podłużna. 
2. Do akt kategorii A należy zaliczyć akta posiadające trwałe historyczne znaczenie polityczne, społeczne i gospodarcze, zarówno dla historii Państwa jak i dla historii Związku Bojowników o Wolność i Demokrację.

3. Do akt kategorii A należy zaliczać akta będące obrazem rozwoju i najistotniejszej działalności Związku Bojowników o Wolność i Demokrację jak również b. Związków kombatanckich, które połączyły się w ZBoWiD w 1949 r. do składu b. Związków zalicza się:

1. Związek Bojowników z Faszyzmem i Najazdem Hitlerowskim o Niepodległość i Demokrację (do 1948 r. Związek Uczestników Walki Zbrojnej o Niepodległość i Demokrację oraz Związek Osadników Wojskowych),

2. Związek byłych Więźniów Politycznych,

3. Związek Dąbrowszczaków,

4. Zwiazek Weteranów Walk Rewolucyjnych 1905 r.,

5. Związek Weteranów Powstań Śląskich,

6. Związek Powstańców Wielkopolskich,

7. Związek Żydów b. Uczestników Walki Zbrojnej z Faszyzmem,

8. Związek Obrońców Westerplatte,

9. Związek Czerwonych Kosynierów,

10. Związek Obrońców Wybrzeża,

11. Stowarzyszenie b. Więźniów Twierdzy Zakroczymskiej.

Do tych akt należy zaliczać przede wszystkim takie akta jak:

a) Statuty Związków oraz regulaminy prac poszczególnych komórek organizacyjnych jak np. Komisji Weryfikacyjnej, Komisji Rewizyjnej itp.,

b) Okólniki i instrukcje dotyczące prac poszczególnych wydziałów i komórek organizacyjnych terenowych,

c) Protokoły z plenarnych posiedzeń kierowniczych organów Związkowych (zjazdy, plenum, prezydium, komisje itp.),

d) Roczne i kwartalne plany pracy poszczególnych komórek organizacyjnych,

e) Akta i dokumenty wartości historycznej: jak wydawnictwa, opisy, zeznania, pisemne wspomnienia uczestników walk wyzwoleńczych, wydawnictwa nielegalne z okresu sanacji czy okupacji hitlerowskiej, fotografie z walk, więzień, obozów, dokumenty zbrodni faszystowskich itp. materiały, które mogą być pomocne w odtworzeniu i opracowaniu dokumentacji do historii walk w okresie 1905-1945,

f) Sprawozdawczość i zestawienia statystyczne z działalności organizacyjnej, propagandowo-politycznej i innej,

g) Kartoteki, arkusze weryfikacyjne, ankiety personalne, ankiety i kartoteki dotyczące odznaczeń członków i personelu etatowego, opinie o członkach i personelu etatowym,

h) Preliminarze budżetowe, bilanse miesięczne, kwartalne, roczne, plany, mapy i szkice budynków, terenu i zabudowań, plany budowlane i techniczne, akta 
i inne dokumenty własności, dokumenty finansowe pierwotne, których termin nie upłynął 10 lat,

i) Korespondencja związana $\mathrm{z}$ istotnymi sprawami związków (telegramy zagraniczne, korespondencja z bratnimi organizacjami kombatanckimi za granicą itp.),

j) Akta i inne dokumenty dotyczące przekazania akt do archiwum państwowego lub na makulaturę

4. Akta kategorii A należy spakować do skrzyń, worków, toreb papierowych itp., zasznuować i zapieczętować w miejscach otwarcia, a następnie przesyłać do Zarządu Głównego w następujących terminach:

1) Białystok, 2) Bydgoszcz, 3) Olsztyn, 4) Warszawa 20 lipca br.

5) Zielona Góra, 6) Kielce, 7) Lublin, 8) Łódź 31 lipca br.

9) Gdańsk, 10) Szczecin, 11) Koszalin, 12) Poznań 15 sierpnia br.

13) Rzeszów, 14) Stalinogród [Katowice - przyp. aut.], 16) Wrocław, 17) Opole 30 sierpnia br.

5. Wszelkie inne akta nie wymienione w pkcie 3 od lit. a) do j) zalicza się do akt kategorii B

6. Akta kategorii B należy podzielić na 2 grupy:

a) akta o charakterze manipulacyjnym - okres przechowywania wynosi 2 lata do tych akt zalicza się:

korespondencja bieżąca między poszczególnymi komórkami organizacyjnymi, mająca charakter zawiadomien, informacji itp., przepustki personalne, dzienniki podawcze, korespondencyjne, listy obecności, zapotrzebowania materiałowe, karty wyjazdów samochodowych, ewidencja podróży służbowych itp.,

b) akta dotyczące działalności ośrodków opiekuńczych oraz innych przedsiębiorstw handlowych prowadzonych przez byłe związki kombatanckie (za wyjątkiem akt, wymienionych w pkcie 3, lit. od a) do j), których okres przechowywania ustala sie na 4 lata

do tych akt zalicza się m.in. takie akta jak dokumentacja magazynowa (wszystkie akta), dokumentacja prowadzenia kuchni, szkolenie wychowanków, prowadzenie świetlic, grzbiety asygnat przychodowych i rozchodowych kasowych, korespondencja z innymi instytucjami (jak Rady Narodowe, organizacje polityczne i społeczne itp.)

7. Akta katgorii B, których okres przechowywania - zgodnie z pktem 6, lit. a) i b) upłynął, winny być przekazane na makulaturę po uprzednim uzyskaniu zezwolenia właściwej władzy archiwalnej (wojewódzkiej, powiatowej).

\section{Tryb pakowania i przedstawiania wniosków}

8. Przy brakowaniu akt kategorii B na makulaturę winna być powołana Komisja składająca się przynajmniej z 3-ch członków:

a) prezesa lub wiceprezesa Zarządu,

b) urzędującego członka Prezydium (w Oddziale Sekretarza), 
c) przedstawiciela Komisji Rewizyjnej.

9. Spis akt wybrakowanych i przeznaczonych na makulaturę powinien zawierać:
a) nazwę i adres Związku,
b) zawartość (treść) akt,
c) daty końcowe,
d) liczba jednostek (paczek, teczek, wiązek).

10. Spis akt powinien obejmować pozycje, odpowiadające każdej teczce lub paczce akt, winien być podsumowany i podpisany przez Komisję.

11. Prezydium Zarządu Okręgu lub Oddziału Powiatowego na podstawie spisu akt, przeznaczonych na makulaturę, sporządzonego przez Komisję wym.[ienioną] w pkcie 9 - opracowuje wniosek o zatwierdzenie brakowania akt i składa ten wniosek właściwej terenowej władzy archiwalnej.

12. Zezwolenia na przekazanie akt na makulaturę wydaje właściwa władza archiwalna w 2-ch egzemplarzach, z których jeden pozostaje w aktach Bojowników o Wolność i Demokrację, drugi przekazuje Związek Bojowników o Wolność i Demokrację wraz z wybrakowaną makulaturą do Zbiornicy Odpadów Użytkowych.

Zarząd Okręgu zobowiązany jest do nadesłania sprawozdania z wykonania tej instrukcji w okresie 10 dni po zakończeniu związanych z tym prac.

Prezydium Zarządu Głównego

Związku Bojowników

o Wolność i Demokrację

Otrzymuja:

Zarządy Okręgowe

Związku Bojowników

o Wolność i Demokrację 